\title{
Türkiye'nin Afetlere Hazırlık Politikalarının Toplum Algısı Üzerinden Karşılaştırmalı Analizi: Van-Bitlis İlleri Örneği
}

\author{
Ahmet Uğur ${ }^{1, *}$, Metin Işık² \\ ${ }^{1}$ Bitlis Eren Üniversitesi, Fen Bilimleri Enstitüsü, Disiplinlerarası Afet Yönetimi, 13000, Bitlis. \\ ${ }^{2}$ Bitlis Eren Üniversitesi, İktisadi ve İdari Bilimler Fakültesi, İşletme Bölümü, 13000, Bitlis.

\section{Özet} \\ Bu araştırmada, Türkiye'nin afetlere hazırlık politikalarının toplum algısı üzerinden karşılaştırmalı olarak incelenmesi amaçlanmıştır. \\ Bu bağlamda, yakın tarihte (2011) afetin yaşandı̆̆ Van ile yakın tarihte herhangi bir afetin yaşanmadı̆̆ Bitlis ilinde bir alan \\ araştırması gerçekleștirilmiştir. Böylelikle afetlere hazırlık politikaları doğrultusunda yapılan uygulamalara yönelik toplum algısının \\ bu iki il arasında herhangi bir farklılık oluşturup oluşturmadığ tespit edilmesi amaçlanmıştır. Araştırmanın ana kütlesini her iki ildeki \\ üniversite personeli, örneklemi ise bu iki üniversiteden araştırmaya gönüllü katılım sağlayan personel oluşturmaktadır. Araştırma \\ kapsamında elde edilen veriler, tanımlayıc istatistiki analizlerin yan sıra, faktör, korelasyon, T testi ve ANOVA analizlerine tabi \\ tutulmuştur. Yapılan analizler sonucunda, genel olarak ülkemizdeki afetlere hazırlık politikalarının etkin bir düzeyde olmadiğı \\ görülmüşürr. Ayrıca, afetin yaşanma durumunun bireylerin afet farkındalı̆̆ ve bilinç düzeyini etkilemediği sonucuna ulaşılmıştır. \\ Araştırma sonuçlarının paydaşlara afete hazırlık konusunda durum tespiti yapma açısından yardımcı olacağı düşünülmektedir. \\ Bununla birlikte sonuçların politika yapıcılara da yol gösterici bir nitelikte katkı sunması beklenmektedir.
}

\section{Community Perception Through Comparative Analysis of Turkey's Disaster Preparedness Policy: The Case of Van-Bitlis Provinces}

\begin{abstract}
In this research, Turkey's perception of society on disaster preparedness policies aimed comparative study. In this context, a field survey was carried out in Van, where the disaster occurred recently (2011) and in Bitlis, where no recent disaster occurred. Thus, it is aimed to determine whether the perception of society regarding the practices made in line with disaster preparedness policies makes any difference between these two provinces. The sample of the research is composed of the staff of the university in each province and the sample is composed of staff who volunteers to participate in the research from these two universities. Data obtained from the research were subjected descriptive statistical analysis, factor, correlation, $T$ test and ANOVA analysis. As a result of the analysis, it was found that in general in our country to an effective level of disaster preparedness policies. In addition, it was concluded that the living situation of the disaster did not affect the disaster awareness level of the individuals. It is thought that the results of the research will be helpful for the determination of the situation in preparation of disaster for the stakeholders. Nevertheless, the results are expected to contribute to policy-makers as well.
\end{abstract}

$\underline{\text { Keywords }}$

Disaster, Disaster Preparedness, Disaster Policies

\section{Giriş}

Afet, insanlarda maddi, ekonomik ve sosyal kayıplara yol açan, toplumun tümünü ya da bir kısmının imkân ve olanaklarının başa çıkmakta yetersiz kaldığı, olağan yaşamını durduran veya aksamasına neden olan doğal, insan kaynaklı ve teknolojik olayların oluşturduğu sonuçlardır (Kadığlu ve Özdamar 2008; UNISDR 2009; Işık vd. 2012). Doğal afetler, jeofizik, meteorolojik, hidrolojik, klimatolojik, biyolojik ve dünya dişındaki olaylardan kaynaklanan afetlere bağlı olarak altı gruba ayrılmaktadır. Deprem, sel, heyelan, çığ, fırtına vb. doğa olaylarını doğal afetlere örnek olarak verilebilir. İnsan kaynaklı veya teknolojik afetler ise endüstriyel, taşıma ve çeşitli kazalar olarak üç grupta ele alınmaktadır. Enerji santralleri kazaları, gaz sızıntısı, çevre kirlenmesi, savaşlar ve ulaştırma araçları kazaları vb. olayları insan kaynaklı veya teknolojik afetler olarak değerlendirebilir (URL-1 2018; CRED 2018). Bunların yanı sıra sosyal afetler de insan kaynaklı afetlere benzer şekilde insanların neden olduğu ve toplumların demografik ve sosyal yapısına derinden etki eden afetlerdir. Göç veya savaşlar sosyal afetlere en uygun örneklerdir. 
Afetler dünyanın neredeyse her bölgesinde meydana gelmekte ve bir bölgeyi etkisi altını alabileceği gibi birçok bölgeyi de etkisi altına alabilmektedir. Örneğin, pasifik bölgesinde meydana gelen depremler Japonya ve Güney Kore gibi son derece gelişmiş ülkelerde bile milyarlarca dolarlık (ABD) zarara sebep olabilmektedir.

Dünyada meydana gelen afetlerin dağılımını incelediğimizde her bölgede benzer ve farklı afetlerin meydana geldiğini görmekteyiz. Afrika ülkeleri kıtlık ve kuraklık gibi doğal afetlerden zarar görürken Güneydoğu Asya ülkeleri sel afetinden zarar görmektedir. Aynı şekilde Pasifik ve bazı Akdeniz ülkelerinin depremlerin etkisini yoğun bir şekilde yaşamaktadır. 1900-2017 yılları arasında dünyada 23.000'ne yakın doğal ve insan kaynaklı afet olayı meydana gelmiştir (CRED 2018). İnsanların yoğun bir şekilde yaşadığı kentlerin sayısının artması, aşırı nüfus artışı, çevresel kirlilik ve doğanın tahrip edilmesi gibi nedenler afetlerin etkisini artırmaktadır. Sadece 1998-2008 yılları arasında dünyada meydana gelen afetlerden 1 milyara yakın insan etkilenmiş, 629 milyar dolarlık (ABD) zarar meydana gelmiştir (Ersoy 2009). Yakın tarihteki verilere bakıldığında, 2017 yıllında dünya genelinde 318 afet meydana gelmiş ve meydana gelen afetler 334 milyarlık dolarlık ekonomik zarara neden olmuştur. Meydana gelen afetlerin 136 tanesi Asya, 42 tanesi Afrika, 39 tanesi Avrupa, 93 tanesi Kuzey ve Güney Amerika ve 8'i Okyanusya kıtalarındaki ülkelerde gerçekleşmiştir. Dünya genelinde afetlerin en çok meydana geldiği ülke ise Çin'dir. Çin'de 2017 yıllında 25 afet meydana gelmiştir (CRED 2018).

Türkiye'nin afetselliği incelendiğinde ise, ülkemizin jeolojik, jeomorfolojik, meteorolojik ve klimatolojik yapısından dolayı doğal afetlerin sıklıkla meydana geldiği ülkeler arasında yer aldığı görülmektedir. TMMOB (2012) verilerine göre Türkiye'nin topraklarının \% 93'ü, nüfusunun \% 98'i ve sanayi kuruluşlarının \% 98'i deprem tehlikesi altındadır. 19002017 yılları arasında Türkiye'de 210 büyük çapta deprem meydana gelmiş, depremlerde 86.802 üstünde insanımız hayatını kaybetmiş ve 597.869.000 konut yıkılmıştır (Ersoy 2009). Türkiye'de deprem, sel, heyelan, çı̆̆, kaya düşmesi, orman yangını, fırtına ve kuraklık gibi doğal afetlerin yanında göç gibi insan kaynaklı afetlerde maddi ve manevi kayıplara neden olmuştur. Büyük afetlerle baş etmek zorunda kalan ülkemiz, Marmara depremi gibi ülke ekonomisine büyük darbe vuran afetler yaşamıştır. Ülkemizde afetler nedeniyle meydana gelen can ve mal kayıplarının fazla olması, ülkemizin afetlere yönelik yasal ve yönetsel çalışmalar üzerinde önemle durmasını zorunlu kılmaktadır. Cumhuriyetin ilk yıllarından itibaren afetlerle ilgili yasal düzenlemeler yapılmaya başlanılmıştır. Ülkemizde yapılan düzenlemelerin önemli bir bölümü afetler meydana geldikten sonra yapılmıştır. Türkiye, Erzincan depreminden sonra afet politikası üretmeye başlamıştır. Çeşitli tarihlerde afet politikasında değişikliğe gidilmiş ve birçok yasal düzenleme yapılmıştır. 1988 yıllında çıkartılan Afetlere İlişkin Acil Yardım Teşkilatı ve Planlama Esaslarına Dair Yönetmelikle devlet kurumları ve toplumun bütün imkânlarını en hızlı ve etkin bir şekilde afetlere müdahale edilmesini ve afetzedelere gerekli yardımların yapılmasını sağlamaya çalışılmıştır. 1999 yıllında meydana gelen Marmara depreminden sonra ülkemiz afet politikasında köklü bir politika değişikliğine gitmiştir. Depremden sonra meydana maddi ve manevi kayıplar afet yönetimi konusunu tekrardan ele almamıza neden olmuştur. Afet yönetiminde yetki kargaşasının önüne geçmek etkin ve koordineli bir yap1 düzenlemek amacıyla İçişleri Bakanlığı'na bağlı Sivil Savunma Genel Müdürlüğü, Bayındırlık ve İskan Bakanlığı’na bağlı Afet İşleri Genel Müdürlüğü ve Başbakanlık’a bağlı Türkiye Acil Durum Yönetimi Genel Müdürlüğü kapatılarak 2009 yılında 5902 sayılı yasa ile Başbakanlık'a bağlı Afet ve Acil Durum Yönetimi Başkanlığı kurulmuştur. 15 Temmuz 2018 tarihinde ise yayınlanan 4 Numaralı Cumhurbaşkanlığı Kararnamesi ile Afet ve Acil Durum Yönetimi Başkanlığı İçişleri Bakanlığına bağlanmıştır (AFAD 2018a).

Afetlere hazırlık politikasına ilişkin alan yazın incelendiğinde, yapılmış olan araştırmaların kapsamının; afet yönetimi (Ertürkmen 2006; Ergünay 2009; Erkal ve Değerliyurt 2009; Kadığlu 2011; Özmen ve Özden 2013) afet riski (Özkul ve Karaman 2007; Erkan 2010; Taştan ve Aydınoğlu 2015), afet politikası ve afetlerin analizi (Balamir 2007; Gökçe vd. 2008; Doğan 2015), afetlerin hukuksal ve kuramsal yapısı (Özkaya ve Erat 2017) üzerinde yoğunluk kazandığ1 görülmektedir. Van ve Bitlis illerinin afet durumuna yönelik yapılan çalışmalar incelendiğinde, Van iline yönelik yapılan araştırmaların; Van ilinin depremselliği (Gündoğdu 2009), afet sonrası yardımlar (Laçiner ve Yavuz 2013) ve afet riski Geyik (2014) gibi konular çerçevesinde gerçekleştirildiği görülmektedir. Bitlis iline yönelik araştırmaların ise; ilin depremselliği (Işık 2013), çı̆̆ riski (Elmastaş ve Özcanlı 2010), doğal afet riski (Ekinci vd. 2018) gibi temalar kapsamında olduğu görülmektedir. İlgili illerde şimdiye kadar afetlere ilişkin yapılan bilimsel çalışmalar incelendiğinde araştırmaların genel olarak, meydana gelen afetlerin sayısal analizi ve afet riskleri üzerinde yoğunlaştığ görülmektedir.

$\mathrm{Bu}$ araştırmada ise AFAD başta olmak üzere ilgili paydaşlar tarafından hazırlanıp uygulanan afet politikalarının toplum algısı üzerinden Van ve Bitlis illerinde karşılaştırmalı bir analizi yapılması amaçlanmıştır. Araştırmada Van ve Bitlis illerinin seçilme edilme nedeni; Van ve Bitlis ilerinin bulunduğu Van gölü havzası birçok doğal afetin meydana geldiği bir bölge olmasıdır. Van ilinde 2011 yıllında meydana gelen depremler Van ve Bitlis illerinin doğal afetler açısından ne derece riskli iller olduğunu ortaya koymuştur. Meteorolojik ve jeolojik yapısından dolayı bölge özellikle doğal afetler açısından ciddi riskler taşımaktadır. Van ilin 1987-2017 yılları arasında klimatolojik ve meteorolojik nedenlerden ötürü 255 ve Bitlis ilinde de 414 afet meydana gelmiştir (Çelik vd. 2017). Her iki ilimizde depremler açısından da son derece ciddi tehlike altında olup, geçmişte büyük depremlere maruz kalmışlardır. Yakın zamanda büyük bir deprem geçiren Van ili toraklarının \%62'si birinci ve \%38'i ikinci derece deprem riski altındadır (Ergünay ve Özmen 2013). Bitlis'te yapılan deprem verilerinin istatiksel dağılımına bakıldığında 50 yıllık bir dönemde ortalama; 6.0 büyüklüğünde bir depremin meydana gelme ihtimali \%90, 6.5 büyüklüğünde bir depremin meydana gelme ihtimali \%61, 7.0 büyüklüğünde bir depremin meydana gelme ihtimali $\% 32$ ve 7.5 büyüklüğünde bir depremin meydana gelme ihtimali \%15 tir. Bitlis ili büyük ve hasar yapıcı depremlerin etkisinde kalmıştır. Geçmişte Bitlis ilinde meydana gelen depremler gelecekte de olacağını göstermektedir (Işık 2013). 
Bitlis ve Van illerinin afetselliğine yönelik bu bilgilerin yanı sıra, her iki ilimizin coğrafi ve kültürel yakınlığı ve bu illerden birinin yakın tarihte (2011 Van) deprem yaşaması, diğerinin (Bitlis) ise yakın tarihte deprem vb. büyük afetler yaşamamış olması bu iki ilin araştırmanın evreni olarak tercih edilme nedenleridir. Bu bağlamda, araştırmada bu iki ilimizde afetlere hazırlık politikaları çerçevesinde yapılan uygulamaların afet yaşayan (Van) ve yakın tarihte yıkıcı bir afet yaşamayan (Bitlis) iller arasında bir farklılık oluşturup oluşturmadığını ve bu illerde afet bilinci noktasında ilgili kurumların yapmış oldukları faaliyetlerin etkinliğinin tespit edilmesi hedeflenmiştir. Araştırma sonuçlarının ilgili paydaşların başta bu iki ilimiz olmak üzere, afetlere hazırlık açısından durum tespiti yapmalarına yardımcı olmasını ayrıca, ilgili politika yapıcılara da yol gösterici bir katkı sunacağı düşünülmektedir.

\section{Türkiye'de Afetlere Hazırlık Politikaları}

Politikalar dayanağını yasal bir düzenlemeden alır ve belirli bir yapı tarafından icra edilir. Bu nedenle politikaların hukuksal ve kurumsal bir boyutu her zaman vardır (Özkaya ve Erat 2017). Politikalar ilgili kişilere yol gösterici niteliğinde olup, etkili ve hızlı karar almalarına yardımcı olur. Bu bakımdan politikalar, kamu, özel, sivil toplum kuruluşları gibi pek çok örgüt tarafından geliştirilebilir. Araştırmamız bağlamında irdelenen afet politikalarının gündeme gelmesinde oluşturulmasında iç ve dış faktörler etkili olmaktadır. Meydana gelen doğal ve teknolojik afetler bu süreçte etkili olmaktadır. Dolayısı ile afet ile ilgili etkinliklerin gündeme gelmesi genellikle bir afetin ardından olmaktadır (Doğan 2015). Yani, afetlere yönelik politikaların afet veya acil durumlar meydana geldikten ve bittikten sonra yasa yapıcılar tarafından ilgili afet olgusuna yönelik politika geliştirdiklerini söyleyebiliriz.

Afetlerle mücadele edebilmenin en etkili yolu, afete sebep olacak tehlikelerin doğuracağı zarar ve kayıpları azaltacak önlemleri afetler olmadan önce almaktır (Ulaş Kadığlu ve Uncu 2018). İnsanoğlu afetlerin bütünüyle önlenmesi, bütününü önleyemiyorsa afetlerin etkilerini en aza indirgemek için çeşitli çalışmalar yapar. Bu çalışmalara afet hazırlık çalışmaları denilmektedir. İnsanoğlu tarihte afetlerle baş edebilmek için çeşitli yollar denemiş ve hazırlıklar yapmıştır. Günümüzde de afetlere hazırlık kapsamında bütün ülkelerde seri çalışmalar yapılmaktadır. Afetlere hazırlık aşamasında asıl hedef zarar azaltma evresine entegre olarak afete etkin bir şekilde müdahale edebilmek, kurum ve personellerin yetki ve sorumluluklarını belirlemek ve destek kaynakların düzenlemesini yapmaktır. Afete hazırlık önlemleri, bir defaya mahsus olarak görülmemeli ve sürekli güncel tutulmalıdır (Şahin 2016).

Uluslararası kuruluşlarca afetlerden sonra yapılan yardımlara olan gereksinmelerin hızla artması, yardımların geri dönüşlerinin sınırlı kalması, tehlikelere karşı duyarsızlıkların ve risk alma eğilimlerinin giderek artması 1980’lerde “yara sarma" politikalarının sorgulanmasına yol açmıştır (Balamir 2007). Yirminci yüzyılda dünyada meydana gelen afetlerin geniş bir coğrafyayı etkisi altına alması ve afetlerden etkilenen insanın sayısının artması afetlere hazırlık kapsamında uluslararası iş birliğini zorunlu hale getirmiştir. Birleşmiş Milletler ve çeşitli uluslararası kuruluşlar afetlere hazırlık kapsamında bütün ülkeleri yakından ilgilendiren çalışmalar yürütmektedir. Bu çalışmaların bazıları; 1987 de Birleşmiş Milletler genel kurulunda kabul edilen 1990-2000 yıllarının Doğal Afetlerin Azaltılması Uluslararası On yılı olarak ilan edilmesi, Yokohama Stratejisi ve Daha Güvenli Bir Dünya İçin Eylem Planı (1994), Binyıl Bildirgesi (2000), Afetlerin Azaltılması Uluslararası Stratejisinin hazırlanması (2000), Birleşmiş Milletler Kalkınma Programı tarafından hazırlanan “Afet Riskinin Azaltılması" küresel raporu (2004), Afet Risklerinin Azaltılması Konferansı ve Hyogo Bildirgesi (2005) ve Hyogo Çerçeve Eylem Planının (2005-2015) hazırlanması, Ulusların ve Toplulukların Afetlere Karşı Dirençlerinin Artırılması ile Risk Azaltma Küresel Platformu (2007) yapılması çalışmalarında doğal afetlerin zararlarının azaltılması konusunda önemli adımlar atılmıştır (URL-2 2014). Hyogo eylem planın sonlanmasından sonra 2015 yıllında Japonya'nın Miyagi eyaletinde 2015-2030 yıllarını kapsayan Sendai bildirge eylem planı imzalanmıştır. Bu eylem planı ile afet risklerinin gelecek planlamasının uzun dönemde daha etkin olacağı beklenmektedir (Macit 2019).

Birleşmiş Milletlerin afetler konusunda ayırdığı bütçe 75 yıl önce yılda küresel gelirin yüzde 0,7'si iken, bu miktar 2000'li yılların başında yüzde 0,2'lere düşmüştür. Küresel gelirin yüzde 1'i dahi olmayan bu bütçeyle başarıya ulaşmak zordur (Ersoy 2009). Az gelişmiş ve gelişmekte olan ülkeler afetlere karşı daha dirençsiz bir yapıda olduğundan uluslararası camianın bu ülkelerin afet politikası çalışmaların etkin rol alması ve afetler konusunda uluslararası çalışmaların yoğunlaştırması gerekmektedir. Dünya'da yapılan afetlere hazırlık çalışmaları gelişmiş ülkelerde bile istenilen aşamada değildir. Birleşmiş milletlerin yaptığı çalışmalar, afetleri önlemede yetersiz kalmaktadır. Günümüzde meydana gelen afetlerin sebep olduğu can ve mal kayıpları, geçmişle kıyaslandığında çok daha fazladır. Yaşanan bu durum uluslararası işbirliğini ve ortak eylemleri yanı sıra ulusal düzeyde politika üreten ve geliştiren kurum ve kuruluş sayısını da etkilemiştir. Bu ayrıcalık, devletleri kendi içinde yeni politikalar geliştirmeye sevk etmiş ve her devlet kendi bölgesinde gerçekleşen afetlere özel politikalar üretmeye başlamıştır. Zaman içinde afet sonrası kriz yönetimi üzerine yoğunlaşan politikalar kendi içinde hatasını fark etmiş, afet öncesi risk yönetimi algısını da bu sürecin içinde eriterek bütünleşik afet yönetimi yapısına evrilmiştir (Özkaya ve Erat 2017).

Doğal afet zamanlarında kırılgan yapının daha büyük sorunlara yol açmaması için, yasal, yönetsel, mali, teknik, eğitsel ve kültürel yönden desteklenen uygulanabilir sağlıklı kent planlaması politikalarına ihtiyaç duyulmaktadır (Güler 2012). Günümüzde yerleşim yerlerinde meydana gelebilecek bir afet sonrasında ortaya çıkabilecek kayıp ve zararlar büyük boyutlarda olabilmektedir. Yaşanan maddi ve manevi kayıplar, toplumun, kurum ve kuruluşların, sivil toplum örgütlerinin, birlikte koordinasyonu ile zarar azaltma ve hazırlık çalışmalarına önem veren, afet sonrasında da nasıl bir strateji belirleyeceğini öngören planlar hazırlanmasını zorunlu kılmıştır (Aydın 2009). 
Tarihte olduğu gibi günümüzde de devletlerin vatandaşlarına karş̧ görev ve sorumlulukları vardır. Devletlerin bekası gereği vatandaşlarını sorunlarına çözümler üretmekle mükelleftir. Devletler kurumları ile vatandaşlarının refahını yükseltmesinin yanında vatandaşlarının can ve mal güvenliğini sağlamak amacıyla çeşitli faaliyetleri yerine getirmesi gerekmektedir. Devletlerin kriz ve risklerin tehlike yaratmaması için gerekli önlemleri alması gerekmektedir.

Ülkemizde bugüne kadar yaşanan afetlerde ortaya çıkan can ve mal kaybının büyük kısmı, afetlere nasıl hazırlanılacağının ve afetlerde nasıl davranılacağının bilinmemesinden kaynaklanmaktadır (AFAD 2012). 1963-2018 yılları arasında uygulanan ülkemizin 10 tane 5 yıllık kalkınma planlamalarının bazılarında afetlere değinilmiştir. 10 . Kalkınma planında Afet yönetimi başlı̆̆ı altında afetlerin analizi, afetlere karşı hedef, amaç ve politikalar belirlenmiştir. 8. Kalkınma planında ise Doğal afetler bölümünde Afetlerin mevcut durumu, afetlere ilişkin Amaçlar, İlkeler ve Politikalar ile Hukuki ve Kurumsal Düzenlemelere yer verilmiştir. Kalkınma planlarında; Türkiye'de 1990'ların sonlarına kadar uygulanan afet politikaları reaktif, afet olduktan sonra yapılan çalışmaların ağırlıklı olduğu yara sarma politikaları ağırlıktadır. Önleme ile ilgili çalışmaların önemsendiği etkin politikalar ise 1999 Marmara Depremleri sonrası ülke gündeminde yoğun olarak yer almıştır (URL-3 2002; URL-4 2013; Tercan 2018). 10 tane 5 yıllık kalkınma planlamalarında afetler için ayrı bir bölüm hazırlanmamıştır. Fakat afet, yerleşme ve kentleşme politikalarıyla ilgili; "konut, çevre ve araştırma-geliştirme faaliyetler" başlıkların alt bölümlerinde yer verilmiştir. Kalkınma planlarında da görüldüğ̈̈ gibi; Türkiye'de 1990'ların sonlarına kadar uygulanan afet politikaları reaktif, afet olduktan sonra yapılan çalışmaların ağırlıklı olduğu yara sarma politikalarıdır. Önleme ile ilgili çalışmaların önemsendiği etkin politikalar ise 1999 Marmara Depremleri sonrası ülke gündeminde yoğun olarak yer almıştır (Tercan 2018).

2009 yılında afetlerin öncesinde ve sonrasında çeşitli amaçlarının yanında yetkin bir afet politikası üretmesi için sorumlu ve yetkili Afet ve Acil Durum Yönetimi Başkanlığı kurulmuştur. Afet ve Acil Durum Yönetimi Başkanlığı kurulması ile afet öncesinde ve sonrasında kurum ve kuruluşlar arasında koordinasyon görevi tek çatı altında toplanmıştır. Afet hazırlık politikası kapsamında tüm devlet kurumlarını ve toplumun neredeyse her kesimi içine alacak kapsamlı bir politika yürütmeye yönelik yasal düzenlemeler çıkarılmaya başlamıştır. Afet ve Acil Durum Yönetimi Başkanlığı’nın kurulması ile il ve ilçelerde afetlere ilişkin afet müdahale planı hazırlamaya başlanılmıştır. Bu gelişme ile afetlere müdahalede merkezi müdahaleden doğan bazı bürokratik sıkıntıların önüne geçilmiş ve yereldeki devlet kurumları sorunları daha kapsamlı bir şekilde ele alınması sağlanmıştır. Ülkemiz afet politikasında önemli dönemeçler geçirmiştir. Bunları aşağıda belirtildiği gibi sıralayabiliriz (Özmen ve Özden 2013);

- 1944 Öncesi Dönem,

- 1944 - 1958 Dönemi,

- 1958 - 1999 Dönemi

- 1999 - 2012 Dönemi

Tablo1: Türkiye'de Afet Yönetimi ve Afetlerle Mücadele Yaklaşım ve Politikalarının Gelişimi 1509 - 2011 Dönemi (Özmen ve Özden 2013)

\begin{tabular}{|c|c|}
\hline Dönem & Afet Politikası \\
\hline $\begin{array}{l}1944 \text { Öncesi (1509 İstanbul } \\
\text { Depremi ile başlayan süreç) }\end{array}$ & $\begin{array}{l}\text { Afet sonrasına yönelik çalışmalar etkindir. Afetleri ilahi ve kadere bağlama anlayış1 } \\
\text { yaygındır. Devletin iyileştirici anlayışı baskındır. }\end{array}$ \\
\hline $\begin{array}{c}1944-1958 \text { (Yer } \\
\text { Sarsıntılarından Evvel ve } \\
\text { Sonra Alınacak Tedbirler } \\
\text { Hakkında Kanun'un yürürlüğe } \\
\text { girmesi ile başlayan süreç) }\end{array}$ & $\begin{array}{l}\text { Afet sonrasın yönelik çalışmalar ağırlıkta olup afet öncesinde çalışmalar sınırlıdır. } \\
\text { Afetleri ilahi ve kadere bağlama anlayışı yaygındır. Devletin iyileştirici anlayış1 } \\
\text { baskındır. }\end{array}$ \\
\hline $\begin{array}{l}1958 \text { - } 1999 \text { (İmar ve İskân } \\
\text { Bakanlığı'nın kuruluşu ile } \\
\text { başlayan süreç) }\end{array}$ & $\begin{array}{l}\text { Bu dönemde afet sonrasına yönelik çalışmalarla beraber yetersiz ve } \\
\text { bütünleştirilmemiş afet öncesi çalışmalar ağılıktadır. Afet sonrasına yönelik } \\
\text { çalışmalarla beraber afet öncesinde bütünleştirilememiş yetersiz politikalar } \\
\text { mevcuttur. Afetleri doğal olaylara doğru yönelme anlayışı başlamışıtır. Afet } \\
\text { öncesinde çalışmalar sınırlıdır. Afetlerde iyileştirici devlet anlayışının devam } \\
\text { etmesinin yanında koruyucu devlet anlayışı başlamıştır. }\end{array}$ \\
\hline $\begin{array}{c}1999-2012(\text { Yıkıcı } 1999 \\
\text { Doğu Marmara Depremleri ile } \\
\text { başlayan süreç) }\end{array}$ & $\begin{array}{l}\text { Afet Sonrası Politikalarda etkin ve sürdürülebilir çalışmalar yapılmaya } \\
\text { başlanılmıştır. Örneğin meydana gelen deprem bölgelerinde zemin çalışmalarının } \\
\text { yapılması ve sağlam zeminli alanların imara açılması Toki ve diğer devlet } \\
\text { kurumlarının depremlere dayanıklı konut yapması. Afet öncesi politikalarında } \\
\text { sakınım ve afetlere hazırlık önem kazanmıştır. Afet öncesi ve sonrasında ortak bir } \\
\text { strateji geliştirme düşüncesi hâkimdir. Afet Risk Yönetimine doğru bir eğilim vardır. } \\
\text { İyileştirici devlet anlayışının yerini koruyucu devlet anlayışı almaya başlamış̧ır. }\end{array}$ \\
\hline
\end{tabular}

Yukardaki tabloda belirtildiği gibi çeşitli dönemlerde ülkemizde afet politikasında değişiklikler yaşanmıştır. Afetlerin sıklıkla meydana gelip büyük kayıplara yol açması sonucunda toplumumuzun afetlere bakışı ve devletin afet politikası değişmeye başlanmıştır. Özellikle büyük afetlerden sonra önemli kararlar almıştır. 
1999 Yaşanan büyük Marmara depremlerinde sonra devlet afet öncesi çalışmalara daha çok yoğunluk vermiştir. 2000 yılından itibaren devletin afetlerdeki koruyucu anlayışı toplum nezdinde yerleşmeye başlamıştır. Türkiye'de afet yönetimi ve koordinasyonu alanında dönüm noktası 1999 Marmara Depremi olmuştur. Büyük can kaybına ve geniş çaplı hasara neden olan bu deprem, ülkemizdeki afet yönetimi sisteminin yetersizliklerini ve dünyada gelişen afet yönetimi anlayışına uygun yeni politikaların geliştirilmesi zorunluluğunu ortaya koymuştur (Azimli Çilingir 2018). Ülkemiz 1999 ve 2000 yıllarında yaptığı yasal çalışmalarla gelecekte muhtemel Marmara depremleri gibi afetlerde can ve mal kaybının meydana gelmemesi için kalıcı ve etkin adımlar atmaya başlamıştır. 2009 yılında Afet ve Acil Durum Yönetim Başkanlığının kurulması ile bazı bürokratik sorunlar aşılmıştır. Afetlerin zararlarını en aza indirmek için çıkarılan yasal düzenlemeler yeterli olsa bile ülkemizde yaptırımdaki aksaklıklardan ötürü istenilen seviyede verim alınmamakta ve yasaların caydırıcılığına gölge düşürmektedir.

Son yıllarda ülkemizde afet farkındalığının artırılmasına yönelik birçok çalışma yürütülmektedir. Afet ve Acil Durum Yönetimi Başkanlığı-AFAD başta olmak üzere Belediyeler ve Milli Eğitim Bakanlığı gibi kurumlar toplumdan afet direnci artırmak için çeşitli faaliyetler düzenlemektedir. Yükseköğretim kurumlarında afet ve afet yönetimine yönelik son yıllarda lisansüstü eğitim vermeye başlayan kurumlar artmıştır. Afet ve Afet Yönetimi alanında, Hacettepe ve Çanakkale 18 Mart Üniversiteleri lisans ve yüksek lisans, Anadolu Üniversitesinde Afet ve Acil Durum Yönetimi ön lisans, Kentleşmede Risk Yönetimi uzaktan öğenim, Dokuz Eylül, Gümüşhane ve Bezmialem üniversitelerinde yüksek lisans ve doktora düzeyinde eğitim verilmektedir. Ülkemizde afetlerle ilgili daha etkin bir strateji yürütülebilmesi için yeni kurumsal yapılar kurulmuştur. Yokohama Strateji Belgesi, Hyogo Protokolü ve Sendai Çerçevesi gibi önemli uluslararası afetlerle ilgili çalışmaların yürütüldüğü organizasyonlar ülkemizde afetlerle ilgi yapılan çalışmalarda çok katkısı olmuştur (Özkaya ve Erat 2017).

\section{Van ve Bitlis İllerinin Afetselliği}

Van ve Bitlis ilerinin bulunduğu Van gölü havzası birçok afetin meydana geldiği bir bölgedir. Meteorolojik ve jeolojik yapısından dolayı bölge özellikle doğal afetler açısından ciddi riskler taşımaktadır. Van ilinde 1987-2017 yılları arasında klimatolojik ve meteorolojik nedenlerden ötürü 255 ve Bitlis ilinde de 414 afet meydana gelmiştir (Çelik vd. 2017). Her iki il depremler açısından da son derece ciddi tehlike altında olup, geçmişte büyük depremlere maruz kalmışlardır. Van ilinde 2011 yıllında meydana gelen depremler Van ve Bitlis illerinin doğal afetler açısından ne derece riskli iller olduğunu ortaya koymuştur. Yakın zamanda büyük bir deprem geçiren Van ili toraklarının \% 62'si birinci ve \% 38'i ikinci derece deprem riski altındadır (Ergünay ve Özmen 2013).

\subsection{Van İlinin Afetselliği}

Van gölü havzası iki önemli tektonik levhanın etkisi altındadır. Bu levhalar Arap ve Avrasya Plakalarıdır. 12. Yüzyılın başından bu yana eldeki veriler incelediğinde Van ilinin tektonik ve volkanik hareketlerin etkisi altında olduğu görülmektedir. 1900 yıllından bu yana Van Gölü bölgesi dikkate alınır ciddi sarsıntılar geçirmiştir. Tarihte meydana gelen 1908 Başkale, 1976 Çaldıran depremleri bu bölgenin depremler açısından büyük riskleri barındırdığı söylenebilir (Karancı vd. 2011). Ayrıca Van ili ülkemizin 1945 yılında hazırlamış olduğu ilk resmi deprem bölgeleri haritasından bu yana büyük depremlerin olduğu aktif fay zonları içeresinde yer almaktadır. 1996 tarihli Türkiye Deprem Bölgeleri haritasında Van ilinin topraklarının \%62'si birinci ve \%38'i ikinci derece olmak üzere tamamı deprem riski altındadır (Ergünay ve Özmen 2013). Yine Van ili deprem haritası incelendiğinde Erciş, Muradiye, Çaldıran, Özalp, Saray, Bahçesaray ve Çatak ilçeleri birinci derece deprem bölgesinde, Van merkez, Edremit, Gevaş, Gürpınar ve Başkale ilçeleri ikinci derece deprem bölgesinde yer almaktadır. Van İli deprem haritası incelendiğinde, Van ilinin büyük bir bölümü birinci derece deprem bölgesi konumunda olduğu ve deprem tehlikesinin çok önemli boyutlarda olduğu görülmekledir (İMO 2010). Nitekim 2011 yılında Van ilinde yıkıcı bir deprem meydana gelmiş ve ilde ciddi can ve mal kayıplarına neden olmuştur.

Yukarda belirtilen depremselliğin yanı sıra, Van ilinin dağlık olmasından dolayın eğimli topraklarının çoğunlukta olması, birçok akarsuyun bulunması ve yerleşim yerlerinin gerekli alt ve üstü yapıdan yoksun olması gibi nedenlerden dolayı Van ili sel afeti açısından ciddi riskler taşımaktadır. Van İlinde daha çok Nisan, Mayıs ve Haziran aylarında seller etkili olmaktadır. İlkbaharda sellerin meydana gelmesinin sebebi karların ve bozların erimesi ile kararsız yağışlardır (Özcan 2006). 1987-2017 yılları arasında Van ilinde 133 sel afeti meydana gelmiştir (Çelik vd. 2017). Diğger taraftan Van ilinde yıllık ortalama karlı gün sayısı 79 olup en yüksek kar örtüsü kalınlığg 106 cm. dir (Kalelioğlu 2018). Van İlin dağlık olması ve kar yağışının fazla olması çığ ihtimalini artırmaktadır. Kış aylarında meydana gelen çığlardan dolayı birçok yerleşim yerinin yolu kapanmaktadır. Bazı yıllarda Hakkâri-Van yollu da meydana gelen çı̆̆lar yüzünden ulaşıma kapanmaktadır. 1987-2017 yılları arasında Van merkez ve ilçelerinde 62 çı̆̆ afeti meydana gelmiştir. Bu yıllar arasında ülkemizde en çok çı̆̆ afetinin meydana geldiği iller arasında Van ili 4. sıradadır (Çelik vd. 2017).

Van ili Valiliği tarafından yayınlanan Van Afetselliği raporuna göre Merkez, Bahçesaray, Çatak, Başkale, Gürpınar ilçelerinde çeşitli tarihlerde heyelan afetine maruz bölge ilan edilmiştir. Van ilinde 1970-2010 yılları arasında 12 Heyelan meydana gelmiştir. Meydana gelen heyelan olaylarında can kaybı yaşanmamış fakat 202 konut ağır zarar görmüştür. 
Aynı rapora göre 1970-2010 yılları arasında Van ilinde 6 Kaya düşmesi olayı meydana gelmiştir. Meydana gelen Kaya düşmesi olaylarında can kaybı yaşanmamış olup 104 konutta ağır hasar meydana gelmiş̧ir.

\subsection{Bitlis İlinin Afetselliği}

Birinci ve ikinci derece deprem bölgesinde yer alan Bitlis ilinin güneyinden geçen Bitlis bindirme kuşağı genellikle Doğu Toros dağlarının güney eteklerini izleyerek doğu-batı doğrultusunda uzanmaktadır. Maraş ve Adıyaman çevresinden başlayan bu kuşak Çüngüş-Ergani-Lice-Kulp-Sason -Kozluk ve Pervari'den geçerek İran'da Zağros kuşağında birleşir. Bitlis Bindirme Kuşağı'nın güneyini oluşturan kıvrımlı kuşak depremsellik açısından son 80 yıllık dönem içerisinde sakin görülmektedir. Depremler daha çok bindirme çizgisine çok yakın yerlerde ve kuzeydedir (MTA 2010). Bitlis ili ve civarında hem tarihsel hem de aletsel dönemde büyük ve hasar yapıcı depremlerin etkisinde kalmıştır. Bu da geçmişte olduğu gibi gelecekte de hasar yapacak depremlerin oluşacağının göstergesidir. Tektonik olarak son derece hareketli kuşaklar içerisinde kalan Van Gölü Havzasında yapılaşma esnasında depremsellik faktörü göz önünde bulundurulmalı ve ilgili yönetmeliklere hassasiyetle uyulmalıdır (Işı1k 2013).

Bitlis şehrinde doğal çevre özelliklerinden kaynaklanan sorunların oluşmasında kuşkusuz klimatik faktörlerin çok önemli bir rolü bulunmaktadır. Sıcaklık değerleri, rüzgârın hızı ve yönü ile yağış gibi faktörler şehirde önemli çevresel sorunlara yol açmaktadır (Alkan 2015). Bitlis ili, Türkiye'de çı̆̆ olaylarının en fazla görüldüğü ildir. Bitlis ilindeki çığ olaylarını etkileyen faktörler (kar örtüsü, rüzgâr, yükselti, eğim, bakı, bitki örtüsü) ile meydana gelen çı̆̆ olayları göz önüne alındığında Bitlis Merkez, Hizan ve Mutki ilçeleri ile Güroymak ve Tatvan ilçelerinin güney kısımları çı̆̆ afet alanı olarak ortaya çıkmıştır. İlde çığ riskinin olduğu 18-55 eğim arasındaki alanlar ilin \%49.5'ni kaplamaktadır. Buna göre ilin yarısına yakını çığ riski altındadır (Elmastaş ve Özcanlı 2010). 1970-2012 yılları arasında yapılan analizlere göre Ülkemizde 220 çığ düşmesi olayı meydana gelmiştir. Bitlis İl ve İlçelerinde 42 yıllık sürede 31 çı̆ afeti meydana gelmiştir (Özşahin 2013).

Bitlis İlinin yeraltı ve yerüstü yapısı ile kar yağışının fazla olması heyelanlar için uygun ortam oluşturur. $\mathrm{Bu}$ nedenlerden ötürü Bitlis ili heyelanlar açısından risk taşımaktadır (Işık ve Özlük 2012). Bitlis İlinde Son 20 yılda AFAD 2018 Raporlarına göre 79 heyelan meydana gelmiştir. Yaşanan heyelan olaylarında ölümler meydana gelmemiş olup bir bina yıkılmıştır (AFAD 2018b). Bitlis ilinin dağlık, eğimli ve çok yağışlı olması gibi faktörlerden ötürü il ciddi kaya düşmesi tehlikesi altındadır. Bitlis ilinde 1958-2000 yılları arasında 13 kaya düşmesi olayı gerçekleşmiş ve bu olaylarda 3.900 kişi kaya düşmesi olayına maruz kalmıştır (Kadıoğlu 2012). Güneydoğu Anadolu bindirme kuşağ üzerinde yer alan Merkez, Mutki ve Hizan ilçeleri göze çarpmaktadır (Işık ve Özlük 2012).

Bitlis yöresi yılda yaklaşık 1206 mm'lik yağış ile ülkemizin en fazla yağış alan yörelerdendir. Fazla yağış alması Bitlis yöresinde taşkın ve sellerin ana nedenleri birini oluşturmaktadır (Alkan 2015). Bitlis ve Erzurum illeri sel afetine en çok maruz kalan illerdir. 1987-2017 yılları arasında Bitlis ilinde 124 sel olayı gerçekleşmiştir (Çelik vd. 2017). Bitlis ilinde yoğun kar yağışı yaşanmakta olup ilin ortalama kar örtüsü kalınlığı 341 cm'dir. Kar yağışı selle neden olan faktörlerden bir tanesidir (OGM 2013). Bitlis ilinde özellikle yağışlı geçen yıllarda seller ve taşkınlar meydana gelmektedir. Bitlis il merkezinde bulunan dereden dolayı meydana gelen taşkınlar birçok iş yerinin ve konutun su altında kalmasına neden olabilmektedir. Yine, il merkezinde çarpık kentleşmenin olması, alt yapının düzenli olmaması, iş yeri ve konutların dere yatağına ya da yakınına yapılması gibi nedenlerden dolayı seller ve taşkınlıklar Bitlis ili için afet riski oluşturmaktadır.

\section{Araştırmanın Metodolojisi}

Araştırmada niceliksel araştırma yöntemi benimsenmiștir. Nicel araştırma paradigması veya niceliksel, sayısal veya istatistiksel araştırma yaklaşımı, ilk ortaya çıkan araşıırma şeklidir. Nicel yaklaşım, görgül (ampirik) yaklaşım olarak da bilinir. Biyoloji, fizik ve mühendislik başta olmak üzere eğitim, psikoloji, sosyoloji, antropoloji ve hukuk gibi sosyal bilimlerde gözlemleme ve ölçüm yoluyla elde edilen verilere dayanır. (Akarsu ve Akarsu 2019). Nicel araştırma modeli olgu ve olayları nesnelleştirerek gözlemlenebilir, ölçülebilir ve sayısal olarak elde edilebilir bir şekilde ortaya koyan bir araştırma modelidir. $\mathrm{Bu}$ araştırmada, niceliksel araştırma modeli içerisinde yer alan betimsel araştırma modeli kullanılmıştır. Betimsel araştırma modeli, bir konudaki herhangi bir durumu saptamayı amaçlar (Karasar 1999). Bu araştırma modelinde öncelikle katılımcıların demografik özellikleri ile ilgili bilgiler verilerek katılımcıların genel bir profili belirlenmeye çalışılmışıı. Daha sonra ise katılımcıların afetlere hazırlık politikalarına yönelik algılarını ölçmek amacıyla tasarlanan ölçek doğrultusunda analizler yapılmıştır.

\subsection{Araştırmanın Amacı ve Hipotezleri}

Ülkemizde afet veya acil durumlara yönelik politika üreten ve bu anlamda yetkili kurum (AFAD) Afet ve Acil Durum Yönetimi Başkanlığı'dır. AFAD her ilde il müdürlükleri aracılığıyla o ilin coğrafik özelliklerinden kaynaklanabilecek olası afet veya acil durumlara yönelik birtakım uygulamalar icra etmektedir. Faaliyetlerini yaparken ilgili kamu kurumları ve birçok sivil toplum örgütüyle birlikte vatandaşı afet öncesi durumlara hazırlama noktasında farkındalık düzeyini artırmaya yönelik çalışmalar yürütmektedir. 
Olası bir afet veya acil durumun meydana getireceği olumsuzlukları asgari düzeye indirebilmek için afet öncesi çalışmaların vatandaşlar tarafından bilinirliliğinin artırılması elzemdir. Afetlere hazırlık politikalarının bu öneminden hareketle bu araştırmada Türkiye'nin afetlere hazırlık politikalarının etkinliği toplum algısı üzerinden karşılaştırılarak incelenmesi hedeflenmiştir. Araştırma yakın zamanda büyük bir afet yaşamış olan Van (2011) ili ile yakın tarihte herhangi bir afet durumu yaşamamış Bitlis ilinde gerçekleştirilmiştir. Bu sayede ilgili kurumların afetin yaşandığı ve yaşanmadığ iki ilde afetlere hazırlık politikalarının etkinliği ve bu politikalar çerçevesinde yapılan faaliyetlerin vatandaşlar tarafından ne düzeyde bilindiği ve iki il arasında farklılık olup olmadığının tespit edilmesi amaçlanmıştır. Araştırma kapsamında aşağıdaki hipotezler geliştirilmiştir:

$\mathbf{H}_{1}$ : Katılımcıların afetlere hazırlık politikalarına yönelik algısı demografik değişkenlerine göre anlamlı bir şekilde farklılaşmaktadır.

$\mathrm{H}_{1 \mathrm{a}}$ : Afetlere hazırlık politikalarına yönelik algı cinsiyete göre anlamlı bir şekilde farklılaşmaktadır.

$\mathrm{H}_{1 \mathrm{~b}}$ : Afetlere hazırlık politikalarına yönelik algı medeni duruma göre anlamlı bir şekilde farklılaşmaktadır.

$\mathrm{H}_{1 \mathrm{c}}$ : Afetlere hazırlık politikalarına yönelik alg1 ikametin mülkiyet durumuna göre anlamlı bir şekilde farklılaşmaktadır.

$\mathrm{H}_{1 \mathrm{~d}}$ : Afetlere hazırlık politikalarına yönelik algı doğrudan afete maruz kalma durumuna göre anlamlı bir şekilde farklılaşmaktadır.

$\mathrm{H}_{1 \mathrm{e}}$ : Afetlere hazırlık politikalarına yönelik algı katılımcı yakınlarının afete maruz kalma durumuna göre anlamlı bir şekilde farklılaşmaktadır.

$\mathrm{H}_{1 \mathrm{f}}$ Afetlere hazırlık politikalarına yönelik algıları ikamet edilen il açsından anlamlı bir şekilde farklılaşmaktadır.

$\mathrm{H}_{1 \mathrm{~g}}$ : Afetlere hazırlık politikalarına yönelik algı ikametin doğal afet sigortası varlığına göre anlamlı bir şekilde farklılaşmaktadır.

$\mathrm{H}_{1 \mathrm{~h}}$ : Afetlere hazırlık politikalarına yönelik algı ikamet süresine göre anlamlı bir şekilde farklılaşmaktadır.

$\mathrm{H}_{11}$ : Afetlere hazırlık politikalarına yönelik algı ikametin afet risk durumuna göre anlamlı bir şekilde farklılaşmaktadır.

$\mathrm{H}_{1 \mathrm{j}}$ : Afetlere hazırlık politikalarına yönelik algı ikametteki kişi sayısına göre anlamlı bir şekilde farklılaşmaktadır.

$\mathrm{H}_{1 \mathrm{k}}$ : Afetlere hazırlık politikalarına yönelik algı afet bilincinin kazandırılmasına yönelik faaliyetler görme değişkenine göre anlamlı bir şekilde farklılaşmaktadır.

$\mathrm{H}_{11}$ : Afetlere hazırlık politikalarına yönelik algı afet politikalarını yürüten aktörleri bilme değişkenine göre anlamlı bir şekilde farklılaşmaktadır.

$\mathrm{H}_{1 \mathrm{~m}}$ : Afetlere hazırlık politikalarına yönelik algı AFAD’ın faaliyetlerini görme değişkenine göre anlamlı bir şekilde farklılaşmaktadır.

$\mathrm{H}_{1 n}$ : Afetlere hazırlık politikalarına yönelik alg1 yapı denetimi yeterliliği değişkenine göre anlamlı bir şekilde farklılaşmaktadır.

\subsection{Araştırmanın Ana Kütlesi ve Örneklemi}

Araştırmaya veri elde etmek amacıyla hazırlanan anket formu için öncelikle Bitlis Eren Üniversitesi Etik İlkeleri ve Etik Kurul Başkanlığından gerekli izin alınmıştır. Araştırmanın ana kütlesini; Bitlis Eren Üniversitesi ve Van Yüzüncü Yıl Üniversitesi'nin akademik ve idari personeli oluşturmaktadır. Örneklemini ise ana kütle içerinden araştırmaya gönüllü katılarak anket formunu yanıtlayan katılımcılar oluşturmaktadır. Örneklemin iki üniversite seçilmesinin nedeni, karşılaştırmalı bir model oluşturabilmektir. Araştırmada örneklem tespitinde basit tesadüfi örnekleme yöntemi seçilmiştir, buna göre, ana kütleyi oluşturan her elemanın örneğe girme şansı eşittir. Dolayısıyla hesaplamalarda da her elemana verilecek ağırlık aynıdır (Arıkan 2004). Veri toplamak amacıyla hazırlanan online anket formu Kasım-Aralık periyodunda Bitlis Eren Üniversitesi ve Van Yüzüncü Yıl Üniversitesi'nin akademik ve idari personelin e-mail adreslerine gönderilmiştir. Yaklaşık olarak 3 hafta kadar beklenmiş ve bu yöntemle istenilen sayıda veri toplanamadığından araştırmacı tarafından anket formu çıktısı alınarak ana kitleye anket formu elden dağıtılmıştır. Sonuç olarak, Bitlis Eren Üniversitesinden 204, Van Yüzüncü Yıl Üniversitesi'nden 234 kişi anket formunu yanıtlanmıştır. Toplam olarak 438 tane yanıtlanan anket değerlendirmeye alınmıştır. Örneklem büyüklüğü açısından \%95 güven aralığında $\% 5$ hata payı ile $n=438$ olarak belirlenmiştir. Bu sayı örneklem büyüklüğü açısından oldukça yeterlidir (Cohen vd. 2005).

\subsection{Veri Toplama Araçları}

Araştırmada veri toplama aracı olarak bir ölçme aracı ve kişisel bilgi formu şeklinde hazırlanan ve iki bölümden oluşan anket kullanılmıştır. Bu kapsamda;

Kişisel bilgi formu; katılımcıların demografik (cinsiyet, yaş, medeni durum, doğrudan afete maruz kaldınız mı? Yakınlarınız herhangi bir afete maruz kaldınız mı? İkamet edilen yer, ikametinizin doğal afet sigortası var mı? Bulunulan ilde ikamet süresi, ikametinizin afet riski taşıdığını düşüyor musunuz? İkamet edilen evdeki kişi sayısı, bulunduğunuz ilde afet bilincinin kazandırılmasına yönelik faaliyetler gördünüz mü? 
Sizce afet politikalarını yürüten aktörler kimlerdir, AFAD’ın hangi faaliyetlerini gördünüz ve bulunduğunuz ilde yapı denetimi yeterli midir) özelliklerine yönelik 13 adet soru yer almaktadır.

Ölçüm aracı; ikinci bölümde, katılımcıların Türkiye’nin afetlere hazırlık politikalarını algı üzerinden ölçmek amacıyla Bulut ve Kara (2016) tarafından geliştirilen ölçek esas alınmış ve araştırmaya uyarlanmıştır. İlgili ölçek 28 soru ve beş boyuttan oluşmaktadır. İlgili ölçekte, 1. Faktör; görevli tüm kurumların afetler ile ilgili çalışmalarıyla ilgili soruların toplanmasından dolayı tüm kurumların çalışmalarına bakış, 2. Faktör; yerel yönetim birimlerinin (afetlerle ilgili çalışmaları ile ilgili sorular toplandığından Yerel yönetimlerin çalışmalarına bakış, 3. Faktör; toplumun afetlere bakışı ve alt yapı ile ilgili soruların toplanmasından dolayı toplumun yaklaşımı ve alt yapıya bakış, 4. Faktör; afetlere karşı alınacak bireysel tedbirlerle ilgili soruların toplanmasından dolayı Bireysel hazırlık ve tedbir düzeyi ve 5. Faktör; AFAD ile ilgili soruların toplanmasından dolayı AFAD ve çalışmalarına bakış şeklinde belirlenmiştir. İlgili ölçüm aracından araştırmamıza 27 ifade uyarlanmıştır. Anket formunda her bir soru için beşli aralıklı 1=kesinlikle katılmıyorum, 2=katılmıyorum, 3=kararsızım, 4=katılıyorum, 5=tamamen katılıyorum şeklinde derecelendirilmiş cevaplar bulunmaktadır.

Tablo 2: Katılımcıların Demografik Bilgileri

\begin{tabular}{|c|c|c|c|c|c|c|c|}
\hline & & \multicolumn{2}{|c|}{ Bitlis } & \multicolumn{2}{|c|}{ Van } & \multicolumn{2}{|c|}{ Toplam } \\
\hline & & $\mathbf{n}$ & $\%$ & $\mathbf{n}$ & $\%$ & $\bar{n}$ & $\%$ \\
\hline \multirow{2}{*}{ Cinsiyet } & Kadın & 65 & 31,9 & 87 & 37,2 & 152 & 34,7 \\
\hline & Erkek & 139 & 68,1 & 147 & 62,8 & 286 & 65,3 \\
\hline \multirow{2}{*}{ Medeni durum } & Evli & 137 & 67,2 & 124 & 53,0 & 261 & 59,6 \\
\hline & Bekar & 67 & 32,8 & 110 & 47,0 & 177 & 40,4 \\
\hline \multirow{2}{*}{ Oturulan evin mülkiyet durumu } & Kendime ait & 78 & 38,2 & 88 & 37,6 & 166 & 37,9 \\
\hline & Kira & 126 & 61,8 & 146 & 62,4 & 272 & 62,1 \\
\hline \multirow{2}{*}{ Doğrudan afete maruz kaldınız mı? } & Evet & 59 & 28,9 & 153 & 65,4 & 212 & 48,4 \\
\hline & Hayır & 145 & 71,1 & 81 & 34,6 & 226 & 51,6 \\
\hline \multirow{2}{*}{$\begin{array}{l}\text { Yakınlarınız herhangi bir afete maruz } \\
\text { kaldı mı? }\end{array}$} & Evet & 79 & 38,7 & 171 & 73,1 & 250 & 57,1 \\
\hline & Hayır & 125 & 61,3 & 63 & 26,9 & 188 & 42,9 \\
\hline \multirow{3}{*}{$\begin{array}{c}\text { İkametinizin doğal afet sigortası var } \\
\text { mı? }\end{array}$} & Var & 78 & 38,2 & 67 & 28,6 & 145 & 33,1 \\
\hline & Yok & 87 & 42,6 & 134 & 57,3 & 221 & 50,5 \\
\hline & Bilgim yok & 39 & 19,1 & 33 & 14,1 & 72 & 16,4 \\
\hline \multirow{5}{*}{$\begin{array}{c}\text { Bulunduğunuz ilde kaç yıldır ikamet } \\
\text { ediyorsunuz }\end{array}$} & 1 yıldan az & 4 & 2,0 & 16 & 6,8 & 20 & 4,6 \\
\hline & $1-5$ & 56 & 27,5 & 51 & 21,8 & 107 & 24,4 \\
\hline & $6-10$ & 79 & 38,7 & 38 & 16,2 & 117 & 26,7 \\
\hline & $11-20$ & 12 & 5,9 & 36 & 15,4 & 48 & 11,0 \\
\hline & 21 ve üzeri & 53 & 26,0 & 93 & 39,7 & 146 & 33,3 \\
\hline \multirow{3}{*}{$\begin{array}{l}\text { Oturduğunuz evin afet riski taşıdığını } \\
\text { düşünüyor muşunuz }\end{array}$} & Evet & 35 & 17,2 & 44 & 18,8 & 79 & 18,0 \\
\hline & Kismen & 85 & 41,7 & 115 & 49,1 & 200 & 45,7 \\
\hline & Hayır & 84 & 41,2 & 75 & 32,1 & 159 & 36,3 \\
\hline \multirow{5}{*}{$\begin{array}{c}\text { Oturduğunuz evde kaç kişi } \\
\text { yaşamaktadır }\end{array}$} & 1 & 24 & 11,8 & 33 & 14,1 & 57 & 13,0 \\
\hline & 2 & 37 & 18,1 & 30 & 12,8 & 67 & 15,3 \\
\hline & 3 & 40 & 19,6 & 47 & 20,1 & 87 & 19,9 \\
\hline & 4 & 43 & 21,1 & 44 & 18,8 & 87 & 19,9 \\
\hline & 5 ve üzeri & 60 & 29,4 & 80 & 34,2 & 140 & 32,0 \\
\hline \multirow{4}{*}{$\begin{array}{l}\text { Afet bilincinin kazandırılmasına } \\
\text { yönelik görsel şeyler gördünüz mü? }\end{array}$} & Görmedim & 118 & 57,8 & 94 & 40,2 & 212 & 48,4 \\
\hline & Nadiren & 59 & 28,9 & 82 & 35,0 & 141 & 32,2 \\
\hline & Ara sıra & 27 & 13,2 & 54 & 23,1 & 81 & 18,5 \\
\hline & Sik sik & - & - & 4 & 1,7 & 4 & ,9 \\
\hline \multirow{7}{*}{$\begin{array}{c}\text { İlinizde afet politikasını yürüten } \\
\text { aktörler kimlerdir }\end{array}$} & Afad & 47 & 23,0 & 38 & 16,2 & 85 & 19,4 \\
\hline & Afad-Valilik & 28 & 13,7 & 13 & 5,6 & 41 & 9,4 \\
\hline & Afad-Belediye & 8 & 3,9 & 15 & 6,4 & 23 & 5,3 \\
\hline & Afad-Valilik-Belediye & 17 & 7,3 & 25 & 10,7 & 42 & 9,6 \\
\hline & Stk'lar & 14 & 6,9 & 25 & 10,7 & 39 & 5,8 \\
\hline & Bilmiyorum & 59 & 28,9 & 69 & 29,5 & 128 & 29,2 \\
\hline & Boş & 31 & 15,2 & 49 & 20,9 & 80 & 18,3 \\
\hline \multirow{6}{*}{$\begin{array}{c}\text { İlinizde AFAD'ın hangi faaliyetlerini } \\
\text { gördünüz }\end{array}$} & Eğitim-Bilgilendirme & 24 & 11,8 & 19 & 8,1 & 43 & 9,8 \\
\hline & Tatbikat & 14 & 6,9 & 21 & 9,0 & 35 & 8,0 \\
\hline & Arama-Kurtarma & 8 & 3,9 & 20 & 8,5 & 27 & 6,2 \\
\hline & Deprem Sonrası Çalışmalar & 4 & 2,0 & 36 & 15,4 & 41 & 9,4 \\
\hline & Görmedim & 118 & 57,8 & 90 & 38,5 & 208 & 47,5 \\
\hline & Boş & 36 & 17,6 & 48 & 20,5 & 84 & 19,2 \\
\hline \multirow{3}{*}{$\begin{array}{c}\text { Bulunduğunuz ilde yapı denetimi } \\
\text { yeterli midir? }\end{array}$} & Evet & 6 & 2,9 & 3 & 1,3 & 9 & 2,1 \\
\hline & Kismen & 65 & 31,9 & 78 & 33,3 & 143 & 32,6 \\
\hline & Hayır & 133 & 65,2 & 153 & 65,4 & 286 & 65,3 \\
\hline
\end{tabular}

Yukarda Tablo 2'de belirtilen demografik bilgiler; araştırmaya her iki ilden toplam 438 kişinin katıldığını ve bunlardan çoğunun erkek ve medeni durum açısından da evli olduklarını göstermektedir. Her iki ilden katılımcıların çoğunun kirada 262' (\%62.1) oturduğu ve 204'ünün (\%48.9) doğrudan afetlere maruz kaldığını görülmektedir. 
Van ilinde afete maruz kalan katılımcıların Bitlis ilinden daha fazla olmasının nedeni 2011 yılında Van meydana gelen depremler olduğu düşünülmektedir. Her iki ildeki katılımcıların büyük bir bölümü evlerinde doğal afet sigortasının olmadığını ya da olup-olmadığını (\%66.9) bilmediğini belirtmişleridir.

Bununla birlikte katılımcıların önemli bir kısmı ikametgâhlarının doğrudan ve kısmen (\%63.7) afet riskini taşıdığını belirtmişleridir. Bitlis ilinde araştırmaya katılanların 118'i (\%57.8), Van ilinde ise 93'ü (\%39.7) afet bilincinin kazandırılmasına yönelik görsel şeyler görmediğini belirtmişlerdir. Van ilindeki katılımcıların "görmedim" yanıtının ortalamasının araştırmada daha düşük çıkması 2011 yıllında ilde meydana gelen depremlerden sonraki çalışmaların etkisi olduğu düşünülmektedir. Diğer taraftan katılımcıların verdiği yanıtlar, toplumda afet bilincinin oluşturulmasına yönelik yapılması gereken görsel faaliyetlerin yetersiz olduğunu göstermektedir.

Katılımcıların çok büyük bir bölümü afet politikasını yürüten aktörlerin başında AFAD, valilik ve belediyenin geldiğini belirtmişlerdir. Ancak katılımcılardan afet politikasını yürüten kurumları bilmediğini ve soruyu boş bırakanların 216 kişi (\%49.4) olması neredeyse katılımcıların yarısına yakınının afet politikalarını yürüten kurumları bilmedikleri görülmüştür. Ayrıca katılımcıların 295’i (\%67.4) AFAD’ın hiçbir faaliyetini görmediğini ya soruyu boş bıraktıkları görülmektedir.

Van ilindeki faaliyetlere bakıldığında deprem sonrası çalışmalar göze çarpmaktadır. Bunun sebebi 2011 yıllında yaşanan depremlerden kaynaklandığ̣ düşünülmektedir. Bu sonuçlar katılımcıların önemli bir bölümünün AFAD il müdürlüklerinin faaliyetlerinin yetersiz bulduklarına işaret etmektedir. Her iki ildeki katılımcıların kamu kurumlarının yapı denetimi konusunda görüşleri birbirine yakındır. Katılımcıların 429'u (\%97.9) illerinde yapı denetiminin kısmen veya yeterli olmadığını beyan etmişlerdir. Bu sonuç, katılımcıların kamu kuruluşlarının yapı denetimi konusundaki çalışmalarını çok yetersiz bulduğunu göstermektedir.

\subsection{Bulgular}

\subsubsection{Güvenilirlik Analizi}

Tablo 3: Güvenilirlik Analizi

\begin{tabular}{|c|c|c|c|c|c|c|c|}
\hline $\begin{array}{l}\text { Ölçek Alt } \\
\text { Boyutları }\end{array}$ & Ortalama & $\begin{array}{l}\text { Standart } \\
\text { sapma }\end{array}$ & $\begin{array}{l}\text { Cronbach's } \\
\text { Alpha }\end{array}$ & $\begin{array}{l}\text { İfade } \\
\text { sayısı }\end{array}$ & $\begin{array}{l}\text { KMO } \\
\text { Değeri }\end{array}$ & $\begin{array}{l}\text { Bartlett's } \\
\text { Test }\end{array}$ & $\begin{array}{l}\text { Varyans } \\
\text { Açılama \% } \\
\end{array}$ \\
\hline $\begin{array}{l}\text { 1. İlgili kurumların faaliyetlerine } \\
\text { yönelik alg1 }\end{array}$ & 2,65 & 7,08 & ,903 & 9 & & & \\
\hline $\begin{array}{l}\text { 2. Bütünsel olarak afetlere } \\
\text { hazırlık }\end{array}$ & 2,18 & 5,10 & ,889 & 6 & & & \\
\hline $\begin{array}{l}\text { 3. Afet sonrası bireysel hazırlık } \\
\text { bilinci }\end{array}$ & 3,15 & 3,79 & ,710 & 5 & ,909 & $0,00 *$ & 62,27 \\
\hline 4. AFAD'a güven & 3,20 & 2,82 & 695 & 4 & & & \\
\hline 5. AFAD bilgisi & 3,00 & 1,94 & 893 & 2 & & & \\
\hline Tüm İfadeleri İçin & 2,75 & 14,87 & ,903 & 26 & & & \\
\hline
\end{tabular}

Tablo 3'de belirtilen KMO ve açıklanan varyans (\%62) değerleri, hazırlanan ölçeğin katılımcıların afetlere hazırlık çerçevesinde yapılan politikaları ve uygulamaları ölçmek için yeterli olduğunu göstermektedir.

\subsubsection{Faktör Analizi}

Yukarda belirtilen güvenilirlik değerleri belirlendikten sonra ölçeğin faktör yapılarına uygunluğunun tespiti için temel bileşenler analizi (Açımlayıcı Faktör Analizi) yapılmıştır. Promax Rotasyonunun uygulandığı temel bilişenler analizi sonucunda beş faktörlü bir yapı oluşturması beklenen "afetlere hazırlık politikalarına yönelik toplum algısı" ölçeğinin beş faktörlü bir yapı oluşturduğu ancak yararlanılan ölçekten farklı şekilde faktörlerin yüklendiği görülmüştür. Yapılan faktör analizinde faktör yükü, 50'nin altında değer aldığı görülen bir ifade analizden çıkarılmıştır. Faktör analizi sonucunda oluşan faktörler ve faktör yükleri aşağıda Tablo 4’te belirtilmiştir. 
Tablo 4: Faktör Analizi

\begin{tabular}{|c|c|c|c|c|c|}
\hline \multirow[b]{2}{*}{ İfadeler } & \multicolumn{5}{|c|}{ Faktörler ve Yükleri } \\
\hline & 1 & 2 & 3 & 4 & 5 \\
\hline $\begin{array}{l}\text { 1. Bulunduğum ilde AFAD'ın afet konusunda hazırlıkları ve çalışmaları } \\
\text { vardır }\end{array}$ & ,754 & & & & \\
\hline $\begin{array}{l}\text { 2. Bulunduğum ilde AFAD afet konusunda görev ve sorumluluklarının } \\
\text { bilincindedir }\end{array}$ & ,748 & & & & \\
\hline $\begin{array}{l}\text { 3. Görevli kurumlar tarafindan afet veya acil durumlar öncesinde, } \\
\text { esnasında veya sonrasında yapılması gerekenlerle ilgili halkı } \\
\text { bilinçlendirme çalışmaları yapılmaktadır }\end{array}$ & ,744 & & & & \\
\hline $\begin{array}{l}\text { 4. Görevli kurumlar tarafından afet ve acil durumlarla ilgili halka } \\
\text { yönelik eğitimler yapılmaktadır }\end{array}$ & ,741 & & & & \\
\hline $\begin{array}{l}\text { 5. Görevli kurumlar tarafından afet ve acil durumlarla ilgili tatbikatlar } \\
\text { yapılmaktadır }\end{array}$ & ,732 & & & & \\
\hline $\begin{array}{l}\text { 6. Görevli kurumlar afet veya acil durumlarla ilgili konularda halka } \\
\text { yeterli ve düzenli bilgilendirme yapmaktadır }\end{array}$ & ,681 & & & & \\
\hline $\begin{array}{l}\text { 7. Görevli kurumlar afet veya acil durumlarla ilgili konularda iş birliği } \\
\text { içerisindeler }\end{array}$ & ,680 & & & & \\
\hline $\begin{array}{l}\text { 8. Bulunduğum ildeki ilgili kurumlar (AFAD, Valilik Belediye, Stk ) bir } \\
\text { afet veya acil duruma karș hazırlıklıdır }\end{array}$ &, 587 & & & & \\
\hline $\begin{array}{l}\text { 9. Görevli kurumlar önceden hazırlık yapmasalar bile bir afetten sonra } \\
\text { gerekli tedbirleri alırlar }\end{array}$ &, 536 & & & , & \\
\hline 10. Bulunduğum ilin imar planı afet risklerine göre göre düzenlenmiştir & & ,841 & & & \\
\hline $\begin{array}{l}\text { 11. Bulunduğum ilin geleceğe yönelik büyüme planları afet riskleri göz } \\
\text { önünde tutularak yapılmaktadır }\end{array}$ & & ,775 & & & \\
\hline $\begin{array}{l}\text { 12. Olası bir afet sonrasinda toplanma alanları ve kullanılacak alternatif } \\
\text { yollar belirlenmiştir }\end{array}$ & & ,769 & & & \\
\hline $\begin{array}{l}\text { 13. Bulunduğum ilde olası bir afet sonrasında yeterli toplanma alanı ve } \\
\text { yol mevcuttur }\end{array}$ & & ,737 & & & \\
\hline $\begin{array}{l}\text { 14. Bulunduğum ildeki insanlar herhangi bir afet veya acil duruma karşı } \\
\text { bilinçli ve duyarlıdır }\end{array}$ & & ,690 & & & \\
\hline $\begin{array}{l}\text { 15. Bulunduğum ildeki insanlar herhangi bir afet veya acil duruma karşı } \\
\text { hazırlıklıdır }\end{array}$ & & ,676 & & & \\
\hline $\begin{array}{l}16 \text { Olası bir afet sonrasında (yıkıcı bir deprem veya sel baskını gibi) ne } \\
\text { yapacağım konusunda planlarım var }\end{array}$ & & & ,757 & & \\
\hline 17. Afet veya acil durumlarda ilk 72 saatin önemini bilirim & & & ,715 & & \\
\hline $\begin{array}{l}\text { 18. Bireysel olarak herhangi bir afet veya acil duruma karşı } \\
\text { hazırlıklıyımdır }\end{array}$ & & & ,641 & & \\
\hline $\begin{array}{l}\text { 19. Herhangi bir afet veya acil duruma karş1 yeterli hazırlık yaparsam } \\
\text { zarar görmeden kurtulabilirim }\end{array}$ & & & ,629 & & \\
\hline $\begin{array}{l}\text { 20. Herhangi bir afet sonrasında arama-kurtarma çalışmalarında gönüllü } \\
\text { olarak çalışırım }\end{array}$ & & &, 526 & & \\
\hline $\begin{array}{l}\text { 21. Herhangi bir afet veya acil durumla karşılaştı̆ıımda AFAD yanımda } \\
\text { olacak ve bana yardım edecektir }\end{array}$ & & & & ,655 & \\
\hline $\begin{array}{l}\text { 22. AFAD'ın olası bir afet veya acil duruma müdahale edecek yeterli } \\
\text { lojistik (personel, iş makinası, malzeme vb.) imkanı vardır. }\end{array}$ & & & & ,641 & \\
\hline $\begin{array}{l}\text { 23. Herhangi bir afet veya acil durum için önceden alınan tedbirler } \\
\text { halkın afetten göreceği zararı azaltır. }\end{array}$ & & & & ,618 & \\
\hline $\begin{array}{l}\text { 24. AFAD bulunduğum ilde meydana gelecek olası bir afet veya acil } \\
\text { durum için gerekli tedbirleri almıştır. }\end{array}$ & & & & ,593 & \\
\hline 25. AFAD'ın görev ve sorumlulukları hakkında yeterince bilgim var. & & & & & ,731 \\
\hline
\end{tabular}

Tablo 4'te belirtilen ifadelerin yüklendiği faktörler ve faktör yüklerinin kabul edilebilir değerler aldığı görülmektedir. Yapılan faktör analizi sonucunda; 1. Faktör: İlgili kurumların faaliyetlerine yönelik algı (KFA); 2. Faktör: Bütünsel olarak afetlere hazırlık (BAH); 3. Faktör: Afet sonrası bireysel hazırlık bilinci (ASH); 4. Faktör: AFAD’a güven (AG); 5. Faktör: AFAD bilgisi $(\mathrm{AB})$ şeklinde adlandırılmış ve parantez içerinde belirtildiği gibi de kodlanmıştır. 
Tablo 5: Korelasyon Analizi

\begin{tabular}{|c|c|c|c|c|c|c|}
\hline & & 1 & 2 & 3 & 4 & 5 \\
\hline (1) KFA & $\begin{array}{l}\text { Pearson Korelasyon } \\
\text { Sig. (2-tailed) }\end{array}$ & - & & & & \\
\hline (2) $\mathrm{BAH}$ & $\begin{array}{l}\text { Pearson Korelasyon } \\
\text { Sig. (2-tailed) }\end{array}$ & $\begin{array}{l}, 607^{* *} \\
, 000\end{array}$ & - & & & \\
\hline (3) $\mathrm{ASH}$ & $\begin{array}{l}\text { Pearson Korelasyon } \\
\text { Sig. (2-tailed) }\end{array}$ & $\begin{array}{l}, 192^{* *} \\
, 000\end{array}$ & $\begin{array}{l}, 157^{* *} \\
, 001\end{array}$ & - & & \\
\hline (4) $\mathrm{AG}$ & $\begin{array}{l}\text { Pearson Korelasyon } \\
\text { Sig. (2-tailed) }\end{array}$ & $\begin{array}{l}, 510^{* * *} \\
, 000\end{array}$ & $\begin{array}{l}, 333^{* *} \\
, 008\end{array}$ & $\begin{array}{l}, 433^{* * *} \\
, 000\end{array}$ & - & \\
\hline (5) $\mathrm{AB}$ & $\begin{array}{l}\text { Pearson Korelasyon } \\
\text { Sig. (2-tailed) }\end{array}$ & $\begin{array}{l}, 246^{* *} \\
, 000\end{array}$ & $\begin{array}{l}199^{* * *} \\
, 000\end{array}$ & $\begin{array}{l}, 542^{* * *} \\
, 000\end{array}$ & $\begin{array}{l}, 462^{* *} \\
, 000\end{array}$ & - \\
\hline
\end{tabular}

** Korelasyon 0.01 düzeyinde anlamlı (2-yönlü)

Tablo 5'e göre afetlere hazırlık politikalarını ölçeğinin alt boyutları arasındaki korelasyon ilișkisi belirtilmiştir. Korelasyon analizine göre ölçeğin bütün alt boyutları arasında pozitif yönlü, güçlü, orta ve zayıf düzeyde ilişkiler olduğu görülmektedir. En yüksek ilişki düzeyinin KFA (İlgili kurumların faaliyetlerine yönelik algı) ile BAH (Bütünsel olarak afetlere hazırlı) boyutları arasında $(\mathrm{r}=, 607 ; \mathrm{p}=0,00)$, en zayıf düzeyde ilişkinin de $\mathbf{B A H}$ (Bütünsel olarak afetlere hazırlık) ile ASH (Afet sonrası bireysel hazırlık bilinci) boyutları arasında $(r=, 157 ; p=0,00)$ olduğu görülmüştür. Bu sonuca göre; afetlere hazırlık politikaları ölçeği ifadelerinin anlamlı bir ilişki yönünün pozitif yönlü ve tutarlığı olduğuna işaret etmektedir.

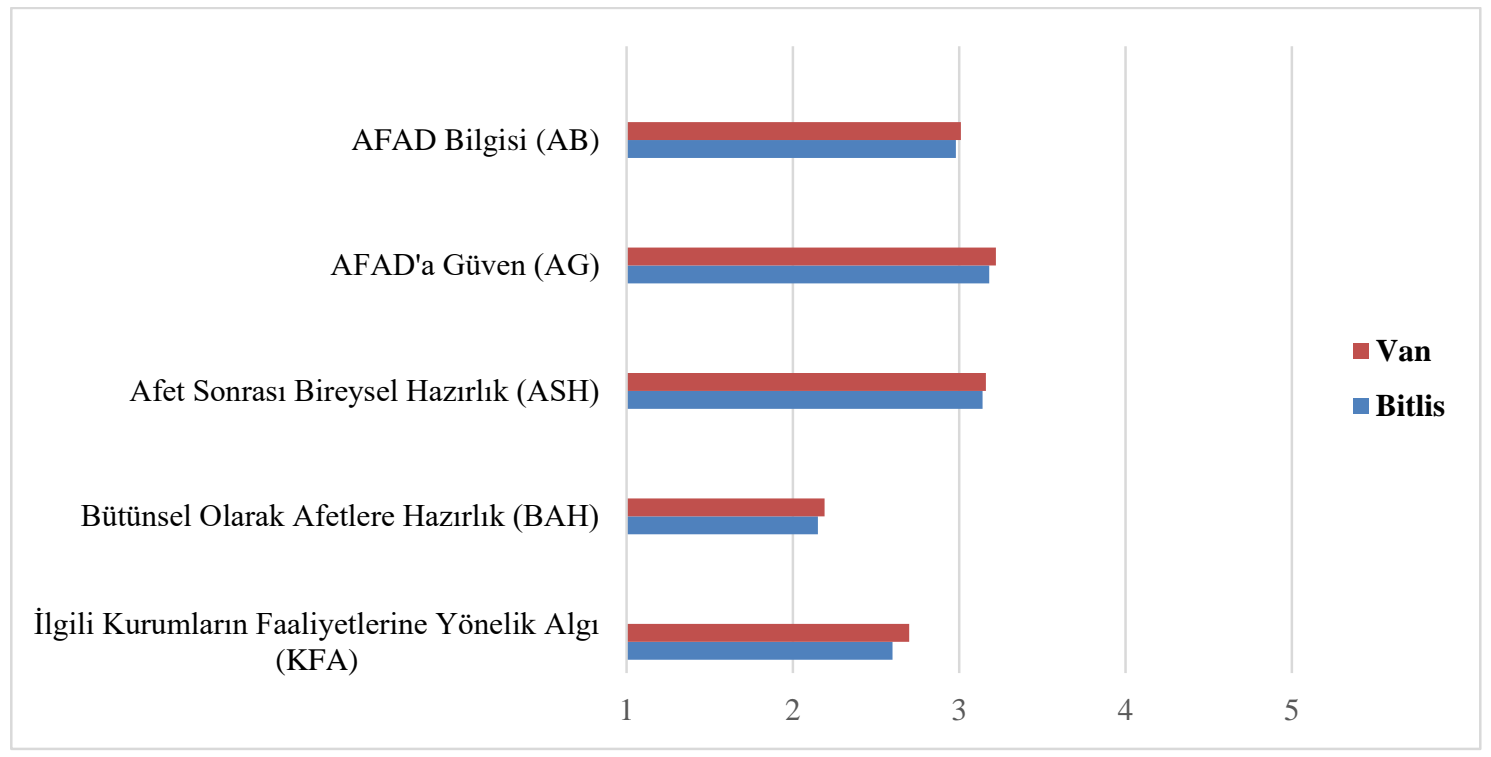

Şekil 1: Ölçek alt boyutlarına Bitlis ve Van ili katılımcılarının verdikleri yanıtların ortalamaları

Araştırma kapsamında katılımcılarının ölçek alt boyutlarına verdikleri yanıtların ortalamalarına bakıldığında; Van ve Bitlis ilerinde en düşük ortalamanın Bütünsel olarak afetlere hazırlık ( $X=2.1890$ ve $X=2.1521)$, en yüksek ortalamanın AFAD'a güven ( $X=3.2137$ ve 3.2137) alt boyutlarına ait olduğu bulgulanmıştır. Bu sonuca göre, katılımcıların AFAD kurumuna olan güvenlerinin yüksek olduğu, diğer taraftan olası bir afet ve acil durumunda toplanma alanları ve kullanılacak alternatif yollar, kentin imar planının afet risklerine göre düzenleme çalışmaları ve afet veya acil duruma karşı hazırlık faaliyetleri hakkında yeterli düzeyde bilgiye sahip olmadıkları görülmüştür.

\subsubsection{Bağımsız Örneklem T Testi}

Katılımcıların afetlere hazırlık politikaları ölçeğinin alt boyutlar itibariyle, değişkenlerden cinsiyet, medeni durum, oturulan evin mülkiyet durumu, doğrudan afete maruz kalma durumu, katılımcıların yakınlarının afete maruz kalma durumu ve ikamet edilen il açısından herhangi bir farklılık oluşturup oluşturmadığını tespit etmek amacıyla bağımsız örneklem T testi analizi yapılmış, anlamlı çıkan sonuçlar aşağıda ilgili tablolarda belirtilmiştir. 
Tablo 6: Katılımcıların afetlere hazırlık politikalarına yönelik algılarının cinsiyet durumu değişkenine göre karşılaştırılması

\begin{tabular}{ccccccc}
\hline $\begin{array}{c}\text { Afetlere Hazırlık Politikaları } \\
\text { Ölçeği Boyutları }\end{array}$ & Cinsiyet & $\begin{array}{c}\text { Kişi } \\
\text { Sayısı }\end{array}$ & Ortalama & $\begin{array}{c}\text { Std. } \\
\text { Sapma }\end{array}$ & t & $\begin{array}{c}\text { Anlamılık } \\
\text { (p) }\end{array}$ \\
\hline $\begin{array}{c}\text { İlgili kurumların faaliyetlerine } \\
\text { yönelik algı (KFA) }\end{array}$ & Kadın & 152 & 2,6534 &, 81200 &, 076 &, 940 \\
\hline Bütünsel olarak afetlere hazırlık & Erkek & 286 & 2,6474 &, 77243 &, 075 &, 941 \\
(BAH) & Kadın & 152 & 2,1855 &, 89790 &, 245 &, 807 \\
\hline \multirow{2}{*}{ Afet sonrası bireysel hazırlık bilinci } & Kadın & 152 & 3,0013 &, 74674 & $-3,034$ &, $\mathbf{0 0 3}$ \\
(ASH) & Erkek & 286 & 3,2301 &, 75358 & $-3,042$ &, $\mathbf{0 0 3}$ \\
\hline \multirow{2}{*}{ AFAD'a güven (AG) } & Kadın & 152 & 3,2072 &, 76165 &, 161 &, 872 \\
& Erkek & 286 & 3,1958 &, 67605 &, 155 &, 877 \\
\hline \multirow{2}{*}{ AFAD bilgisi (AB) } & Kadın & 152 & 2,9408 &, 99325 &,- 912 &, 362 \\
& Erkek & 286 & 3,0297 &, 95970 &,- 902 &, 368 \\
\hline
\end{tabular}

Tablo 6'da görüldüğü gibi cinsiyet değişkenine göre afet afetlere hazırlık politikalarına ilişkin tutum ölçeğinin “afet sonrası bireysel hazırlık bilinci" alt boyutunda erkek katılımcılar lehine anlamlı bir fark gözlenmektedir $(p<0.05)$. Afet sonrası bireysel hazırlık bilinci boyutunda hem erkek hem de kadın katılımcıların tutumları "ne katılıyorum ne katılmıyorum" düzeyinde olmasına rağmen aritmetik ortalamalara bakıldığında erkek katılımcıların afetlere hazırlık politikalarının afet sonrası bireysel hazırlık bilinci boyutuna ilişkin tutumları $(X=3,2301)$ kadın katılımcılara $(X=3,0013)$ göre daha olumlu yöndedir. Bu bulgu erkek katılımcıların afet sonrası bireysel hazırlık bilincinin kadın katılımcılara göre biraz daha fazla olumlu olduğunu göstermektedir. Diğer alt boyutlarda cinsiyet değişkenine göre anlamlı bir farklılık gözlenmemektedir $(\mathrm{p}>0.05)$.

Tablo 7: Katılımcıların afetlere hazırlık politikalarına yönelik algılarının medeni durum değişkenine göre karşılaştırılması

\begin{tabular}{ccccccc}
\hline $\begin{array}{c}\text { Afetlere Hazırlık Politikaları } \\
\text { Ölçeği Boyutları }\end{array}$ & $\begin{array}{c}\text { Medeni } \\
\text { durum }\end{array}$ & $\begin{array}{c}\text { Kişi } \\
\text { Sayısı }\end{array}$ & Ortalama & $\begin{array}{c}\text { Std. } \\
\text { Sapma }\end{array}$ & t & $\begin{array}{c}\text { Anlamlılık } \\
\text { (P) }\end{array}$ \\
\hline $\begin{array}{c}\text { İlgili kurumların faaliyetlerine } \\
\text { yönelik algı (KFA) }\end{array}$ & Evli & 261 & 2,6841 &, 78001 & 1,121 &, 263 \\
\hline Bütünsel olarak afetlere hazırlık & Bekar & 177 & 2,5984 &, 79288 & 1,118 &, 264 \\
(BAH) & Evli & 261 & 2,1943 &, 83124 &, 669 &, 504 \\
\hline Afet sonrası bireysel hazırlık bilinci \\
(ASH) & Bekar & 177 & 2,1388 &, 88043 &, 662 &, 508 \\
\hline \multirow{2}{*}{ AFAD'a güven (AG) } & Bekar & 177 & 3,0537 &, 81847 & 2,155 &, $\mathbf{0 3 2}$ \\
\hline \multirow{2}{*}{ AFAD bilgisi (AB) } & Evli & 261 & 3,1686 &, 66810 & $-1,123$ &, 262 \\
& Bekar & 177 & 3,2458 &, 75823 & $-1,096$ &, 274 \\
\hline
\end{tabular}

Tablo 7'de görüldüğü gibi medeni durum değişkenine göre afet afetlere hazırlık politikalarına ilişkin tutum ölçeğinin "afet sonrası bireysel hazırlık bilinci” alt boyutunda evli katılımcılar lehine anlamlı bir fark gözlenmektedir ( $p<0.05$ ). Afet sonrası bireysel hazırlık bilinci boyutunda hem evli hem de bekâr katılımcıların tutumları "ne katılıyorum ne katılmıyorum" düzeyinde olmasına rağmen aritmetik ortalamalara bakıldığında evli katılımcıların afetlere hazırlık politikalarının afet sonrası bireysel hazırlık bilinci boyutuna ilişkin tutumları $(X=3,2165)$ bekâr katılımcılara $(X=3,0537)$ göre daha olumlu yöndedir. Bu bulgu evli katılımcıların afet sonrası bireysel hazırlık bilincinin bekâr katılımcılara göre biraz daha olumlu olduğunu göstermektedir. Ölçeğin diğer alt boyutları ile medeni durum değişkenine göre anlamlı bir farklılık olmadığ 1 görülmektedir $(\mathrm{p}>0.05)$. 
Tablo 8: Katıımcıların afetlere hazırlık politikalarına yönelik algılarının ikamet durum değişkenine göre karşılaştırılması

\begin{tabular}{|c|c|c|c|c|c|c|}
\hline $\begin{array}{c}\text { Afetlere Hazırlık Politikaları } \\
\text { Ölçeği Boyutları }\end{array}$ & $\begin{array}{c}\text { İkametin Mülkiyet } \\
\text { Durumu }\end{array}$ & $\begin{array}{c}\text { Kişi } \\
\text { Sayısı }\end{array}$ & Ortalama & $\begin{array}{l}\text { Std. } \\
\text { Sapma }\end{array}$ & $\mathbf{t}$ & $\begin{array}{l}\text { Anlamlılık } \\
\text { (P) }\end{array}$ \\
\hline \multirow{2}{*}{$\begin{array}{l}\text { İlgili kurumların faaliyetlerine } \\
\text { yönelik alg1 (KFA) }\end{array}$} & Kendime ait & 164 & 2,6636 & 81410 & ,294 &, 769 \\
\hline & Kira & 274 & 2,6408 & ,76886 & ,290 & ,772 \\
\hline \multirow{2}{*}{$\begin{array}{l}\text { Bütünsel olarak afetlere hazırlık } \\
\text { (BAH) }\end{array}$} & Kendime ait & 164 & 2,2353 & ,87661 & 1,221 & ,223 \\
\hline & Kira & 274 & 2,1331 & ,83407 & 1,206 & ,229 \\
\hline \multirow{2}{*}{$\begin{array}{l}\text { Afet sonrası bireysel hazırlık bilinci } \\
\text { (ASH) }\end{array}$} & Kendime ait & 164 & 3,1925 & ,77917 & ,901 & ,368 \\
\hline & Kira & 274 & 3,1252 & ,74547 & ,891 & ,373 \\
\hline \multirow{2}{*}{ AFAD'a güven (AG) } & Kendime ait & 164 & 3,2455 & ,70078 & 1,059 & 290 \\
\hline & Kira & 274 & 3,1719 & ,70913 & 1,062 & ,289 \\
\hline \multirow{2}{*}{ AFAD bilgisi (AB) } & Kendime ait & 164 & 3,1235 & ,98077 & 2,106 & ,036 \\
\hline & Kira & 274 & 2,9228 & ,95928 & 2,095 & ,037 \\
\hline
\end{tabular}

Tablo 8'de görüldüğü gibi ikametin mülkiyet durumu değişkenine göre afetlere hazırlık politikalarına ilişkin tutum ölçeğinin "AFAD bilgisi” alt boyutunda oturulan evin kendisine ait olan katılımcılar lehine anlamlı bir fark gözlenmektedir $(\mathrm{p}<0.05)$. AFAD bilgisi alt boyutunda aritmetik ortalamalara bakıldığında ikametin mülkiyet durumu kendisine ait olan katılımcıların afetlere hazırlık politikalarının AFAD bilgisi boyutuna ilişsin tutumları $(\mathrm{X}=3,1235)$ ikametin mülkiyet durumu kira olan katılımcılara $(X=2,9228)$ göre daha olumlu yöndedir. Bu bulgu ikamet ettiği evin kendisine ait olan katılımcıların AFAD bilgisinin ikamet ettiği kira olan katılımcılara göre biraz daha fazla olumlu olduğunu göstermektedir. Diğer alt boyutlarda ikametin mülkiyet durumu değişkenine göre anlamlı bir farklılık olmadığı görülmüştür ( $\mathrm{p}>0.05)$.

Tablo 9: Katılımcıların afetlere hazırlık politikalarına yönelik algılarının doğrudan afete maruz kalma değişkenine göre karşılaştırılması

\begin{tabular}{|c|c|c|c|c|c|c|}
\hline $\begin{array}{c}\text { Afetlere Hazırlık Politikaları } \\
\text { Ölçeği Boyutları }\end{array}$ & $\begin{array}{c}\text { Doğrudan Afete Maruz } \\
\text { Kaldınız Mı? }\end{array}$ & $\begin{array}{c}\text { Kişi } \\
\text { Sayısı }\end{array}$ & Ortalama & $\begin{array}{c}\text { Std. } \\
\text { Sapma }\end{array}$ & $\mathbf{t}$ & $\begin{array}{l}\text { Anlamlılık } \\
\text { (P) }\end{array}$ \\
\hline \multirow{2}{*}{$\begin{array}{l}\text { İlgili kurumların faaliyetlerine } \\
\text { yönelik alg1 (KFA) }\end{array}$} & Evet & 214 & 2,7245 & ,79955 & 1,942 & .053 \\
\hline & Hayır & 224 & 2,5791 &, 76713 & 1,940 &, 053 \\
\hline \multirow{2}{*}{$\begin{array}{c}\text { Bütünsel olarak afetlere hazırlık } \\
\text { (BAH) }\end{array}$} & Evet & 214 & 2,1954 & ,91874 & ,561 &, 575 \\
\hline & Hayır & 224 & 2,1497 & ,78336 & ,559 & ,577 \\
\hline \multirow{2}{*}{$\begin{array}{l}\text { Afet sonrası bireysel hazırlık bilinci } \\
\text { (ASH) }\end{array}$} & Evet & 214 & 3,2519 & ,77798 & 2,725 & ,007 \\
\hline & Hayır & 224 & 3,0558 & ,72823 & 2,719 & ,007 \\
\hline \multirow{2}{*}{ AFAD'a güven (AG) } & Evet & 214 & 3,1985 & ,74008 &,- 036 & ,971 \\
\hline & Hayır & 224 & 3,2010 & ,67428 &,- 036 & ,971 \\
\hline \multirow{2}{*}{ AFAD bilgisi (AB) } & Evet & 214 & 3,1014 & ,95904 & 2,149 & ,032 \\
\hline & Hayır & 224 & 2,9026 & 97491 & 2,151 &, 032 \\
\hline
\end{tabular}

Tablo 9'da belirtildiği gibi katılımcıların doğrudan afete maruz kalma durumlarının afetlere hazırlık politikalarına ilişkin tutum ölçeğinin "afet sonrası bireysel hazırlık bilinci" alt boyutunda afete maruz kalan (evet diyen) katılımcılar lehine anlamlı bir fark gözlenmektedir $(\mathrm{p}<0.05)$. Afet sonrası bireysel hazırlık bilinci boyutunda gerek doğrudan afete maruz kalanlar gerekse doğrudan afete maruz kalmayan katılımcıların tutumları "ne katılıyorum ne de katılmıyorum" düzeyinde olmasına rağmen aritmetik ortalamalara bakıldığında doğrudan afete maruz kalan katılımcıların afet sonrası bireysel hazırlık bilincinin $(X=3,2519)$ doğrudan afete maruz kalmayan katılımcılara $(X=3,0558)$ göre daha olumlu yöndedir. Bu bulgu doğrudan afete maruz kalan katılımcıların afet sonrası bireysel hazırlık bilincinin doğrudan afete maruz kalmayan katılımcılara göre daha yüksek olduğunu göstermektedir. Benzer şekilde doğrudan afete maruz kalan katılımcıların AFAD bilgisinin $(X=3,1014)$ doğrudan afete maruz kalmayan katılımcılara $(X=2,9026)$ göre daha olumlu olduğu tespit edilmiştir. Diğer alt boyutlar ile katılımcıların doğrudan afete maruz kalma durumları arasında anlamlı bir farklılık olmadığı tespit edilmiştir ( $\mathrm{p}>0.05)$. 
Tablo 10: Katılımcıların afetlere hazırlık politikalarına yönelik algılarının katılımcı yakınlarının afete maruz kalma değişkenine göre karşılaştırılması

\begin{tabular}{|c|c|c|c|c|c|c|}
\hline $\begin{array}{c}\text { Afetlere Hazırlık Politikaları } \\
\text { Ölçeği Boyutları }\end{array}$ & $\begin{array}{l}\text { Yakınlarınız Afete } \\
\text { Maruz Kaldınız Mı? }\end{array}$ & $\begin{array}{c}\text { Kişi } \\
\text { Sayısı }\end{array}$ & Ortalama & $\begin{array}{c}\text { Std. } \\
\text { Sapma }\end{array}$ & $\mathbf{t}$ & $\begin{array}{l}\text { Anlamlılık } \\
\text { (P) }\end{array}$ \\
\hline \multirow{2}{*}{$\begin{array}{l}\text { İlgili kurumların faaliyetlerine } \\
\text { yönelik alg1 (KFA) }\end{array}$} & Evet & 250 & 2,7004 & ,81582 & 1,568 &, 118 \\
\hline & Hayır & 188 & 2,5817 & ,73990 & 1,590 &, 113 \\
\hline \multirow{2}{*}{$\begin{array}{l}\text { Bütünsel olarak afetlere hazırlık } \\
\text { (BAH) }\end{array}$} & Evet & 250 & 2,1936 & ,89449 & ,616 &, 538 \\
\hline & Hayır & 188 & 2,1429 & ,79064 & ,627 &, 531 \\
\hline \multirow{2}{*}{$\begin{array}{l}\text { Afet sonrası bireysel hazırlık bilinci } \\
\text { (ASH) }\end{array}$} & Evet & 250 & 3,1890 & ,79497 & 1,220 & ,223 \\
\hline & Hayır & 188 & 3,0997 &, 70530 & 1,241 &, 215 \\
\hline \multirow{2}{*}{ AFAD'a güven (AG) } & Evet & 250 & 3,1990 & ,73437 &,- 026 & ,979 \\
\hline & Hayır & 188 & 3,2008 & ,66854 &,- 027 & 979 \\
\hline \multirow{2}{*}{ AFAD bilgisi (AB) } & Evet & 250 & 3,0480 & 1,00386 & 1,222 & ,222 \\
\hline & Hayır & 188 & 2,9335 & ,92474 & 1,236 &, 217 \\
\hline
\end{tabular}

Tablo 10'da da görüldüğü üzere katılımcılara yakınlarının herhangi bir afete maruz kalıp kaldıkları sorusu yöneltilmiştir. Bu soru doğrultusunda yapılan $\mathrm{T}$ testi sonucu katılımcı yakınlarının herhangi bir afete maruz kalmaları ile afetlere hazırlık politikalarına yönelik algıları arasında anlamlı bir farklılık olmadığı tespit edilmiştir ( $\mathrm{p}>0.05)$.

Tablo 11: Katıımcıların afetlere hazırlık politikalarına yönelik algının ikamet ettikleri il değişkenine göre karşılaştırılması

\begin{tabular}{ccccccc}
\hline $\begin{array}{c}\text { Afetlere Hazırlık Politikaları } \\
\text { Ölçeği Boyutları }\end{array}$ & İkamet & $\begin{array}{c}\text { Kişi } \\
\text { Sayısı }\end{array}$ & Ortalama & $\begin{array}{c}\text { Std. } \\
\text { Sapma }\end{array}$ & t & $\begin{array}{c}\text { Anlamlılık } \\
\text { (P) }\end{array}$ \\
\hline $\begin{array}{c}\text { İlgili kurumların faaliyetlerine } \\
\text { yönelik algı (KFA) }\end{array}$ & Bitlis & 204 & 2,5964 &, 81768 & $-1,321$ &, 187 \\
\hline Bütünsel olarak afetlere hazırlık & Van & 234 & 2,6957 &, 75498 & $-1,313$ &, 190 \\
(BAH) & Bitlis & 204 & 2,1521 &, 84871 &,- 452 &, 651 \\
\hline \multirow{2}{*}{ Afet sonrası bireysel hazırlık bilinci } & Van & 234 & 2,1890 &, 85425 &,- 452 &, 651 \\
(ASH) & Bitlis & 204 & 3,1363 &, 74964 &,- 371 &, 711 \\
\hline \multirow{2}{*}{ AFAD’a güven (AG) } & Van & 234 & 3,1632 &, 76704 &,- 372 &, 710 \\
\hline \multirow{2}{*}{ AFAD bilgisi (AB) } & Bitlis & 204 & 3,1838 &, 67258 &,- 441 &, 659 \\
& Van & 234 & 3,2137 &, 73520 &,- 444 &, 658 \\
\hline
\end{tabular}

Tablo 11'de afetlere hazırlık politikaları ölçeğine verdikleri yanıtlar ile katılımcıların ikamet ettikleri il arasında herhangi bir farklılık olup olmadığına bakılmıştır. Tablodan da görüleceği üzere katılımcıların ikamet ettikleri il ile afetlere hazırlık politikaları ölçeğine verdikleri yanıtlarının ortalamaları arasında anlamlı bir farklılık olmadığı görülmüştür ( $\mathrm{p}>0.05$ ). Dolayısıyla bu durum afetlere hazırlık politikalarının, afetin yaşandığı Van ve yaşanmadığı Bitlis ili arasında bir farklılık oluşturmadığını göstermektedir.

\subsubsection{Anova Analizi}

Afetlere hazırlık politikaları ölçeğinin alt boyutlar itibariyle katılımcıların; ikametin doğal afet sigortası varlığı, bulunulan ilde ikamet süresi, ikametin afet riski taşıma durumu, ikametteki kişi sayısı, afet bilincinin kazandırılmasına yönelik faaliyetler görme durumu, afet politikalarını yürüten aktörlerin kimler olduğu, AFAD'ın hangi faaliyetlerini gördünüz ve bulunduğunuz ilde yapı denetimi yeterli midir şeklindeki değişkenler ile karşılaştırılmasına yönelik ANOVA analizi yapılmıştır. ANOVA analizinde PostHoc testlerinden TukeyHSD ile çoklu karşılaştırma yapılmış ve Homojenlik testine göre sadece anlamlı farklılık gösteren boyutlar ve değişkenler dikkate alınmıştır. 
Tablo 12: Katılımcıların afetlere hazırlık politikaları algısı ile alt boyutların ikametleri doğal afet sigortası değişkenine göre karşılaştırılması

\begin{tabular}{|c|c|c|c|c|c|}
\hline Ölçek Alt Boyutları & DASK Var mı? & Ortalama & Std. Sapma & $\mathbf{F}$ & $\mathbf{P}$ \\
\hline \multirow{3}{*}{$\begin{array}{l}\text { İlgili kurumların faaliyetlerine } \\
\text { yönelik algı (KFA) }\end{array}$} & Var & 2,7020 & ,76527 & \multirow{3}{*}{, 484} & \multirow{3}{*}{,616 } \\
\hline & Yok & 2,6235 & ,81852 & & \\
\hline & Bilgim yok & 2,6232 & ,72467 & & \\
\hline \multirow{3}{*}{$\begin{array}{l}\text { Bütünsel olarak afetlere hazırlık } \\
\text { (BAH) }\end{array}$} & Var & 2,1722 & ,81124 & \multirow{3}{*}{,003 } & \multirow{3}{*}{,997 } \\
\hline & Yok & 2,1739 & 88217 & & \\
\hline & Bilgim yok & 2,1648 & 84270 & & \\
\hline \multirow{3}{*}{$\begin{array}{l}\text { Afet sonrası bireysel hazırlık } \\
\text { bilinci (ASH) }\end{array}$} & Var & 3,2121 & ,79031 & \multirow{3}{*}{, 853} & \multirow{3}{*}{,427 } \\
\hline & Yok & 3,1068 & ,74333 & & \\
\hline & Bilgim yok & 3,1618 & ,73884 & & \\
\hline \multirow{3}{*}{ AFAD'a güven (AG) } & Var & 3,2569 & ,66140 & \multirow{3}{*}{4,615} & \multirow{3}{*}{, 010} \\
\hline & Yok & 3,1063 & ,72957 & & \\
\hline & Bilgim yok & 3,3715 & 68432 & & \\
\hline \multirow{3}{*}{ AFAD bilgisi (AB) } & Var & 3,1103 & ,98858 & \multirow{3}{*}{1,454} & \multirow{3}{*}{,235 } \\
\hline & Yok & 2,9367 & 97959 & & \\
\hline & Bilgim yok & 2,9653 & 90120 & & \\
\hline
\end{tabular}

Afetlere hazırlık politikaları alt boyutları ile katılımcıların ikametinin doğal sigortası olup olmadıklarının karşılaştırılmasına ait ortalama puanları tabloda görülmektedir. Tablo 12'de görüldüğü gibi ikametin doğal sigortası değiş̧kenine göre yapılan karşılaştırmada "AFAD'a güven" alt boyutu ortalama puanları arasında istatistiksel olarak anlamlı farklılık belirlenmiştir $(\mathrm{p}<0,05)$. AFAD'a güven alt boyutu itibariyle doğal afet sigortasının olup olmadıkları hakkında bilgim yok ve var diyenlerin yok diyenlerden anlamlı düzeyde daha yüksek ortalamaya sahip oldukları görülmüştür $\mathrm{p}<0,05$. Diğer taraftan tabloda görüldüğü gibi afetlere hazırlık politikalarına yönelik algı ölçeğinin doğal afet sigortası değişkenine göre yapılan karşılaştırmada ortalama puanları arasında istatistiksel olarak anlamlı farklılık belirlenmemiştir $p>0,05$.

Tablo 13: Katılımcıların afetlere hazırlık politikaları algısı ile alt boyutların ikamet süresi değişkenine göre karşılaştırılması

\begin{tabular}{|c|c|c|c|c|c|}
\hline Ölçek Alt Boyutları & İkamet Süresi & Ortalama & Std. Sapma & $\mathbf{F}$ & $\mathbf{P}$ \\
\hline \multirow{5}{*}{$\begin{array}{l}\text { İlgili kurumların } \\
\text { faaliyetlerine yönelik } \\
\text { alg1 (KFA) }\end{array}$} & 1 y1ldan az & 2,4444 & ,75100 & \multirow{5}{*}{1,794} & \multirow{5}{*}{, 129} \\
\hline & $1-5$ & 2,6346 & ,79647 & & \\
\hline & $6-10$ & 2,5353 & ,72345 & & \\
\hline & $11-20$ & 2,7014 & 80063 & & \\
\hline & 21 ve üzeri & 2,7628 & ,81544 & & \\
\hline \multirow{5}{*}{$\begin{array}{l}\text { Bütünsel olarak } \\
\text { afetlere hazırlık } \\
\text { (BAH) }\end{array}$} & 1 y1ldan az & 1,9083 & ,57092 & \multirow{5}{*}{1,319} & \multirow{5}{*}{262} \\
\hline & $1-5$ & 2,2495 & ,88410 & & \\
\hline & $6-10$ & 2,0687 & ,78603 & & \\
\hline & $11-20$ & 2,1771 & ,93678 & & \\
\hline & 21 ve üzeri & 2,2319 & 87349 & & \\
\hline \multirow{5}{*}{$\begin{array}{l}\text { Afet sonrası bireysel } \\
\text { hazırlık bilinci (ASH) }\end{array}$} & 1 y1ldan az & 2,9600 & ,79366 & \multirow{5}{*}{1,004} & \multirow{5}{*}{,405 } \\
\hline & $1-5$ & 3,0967 & 69643 & & \\
\hline & $6-10$ & 3,1098 & 69083 & & \\
\hline & $11-20$ & 3,2375 & ,88164 & & \\
\hline & 21 ve üzeri & 3,2205 & ,80369 & & \\
\hline \multirow{5}{*}{ AFAD’a güven (AG) } & 1 y1ldan az & 3,2250 & ,76906 & \multirow{5}{*}{,965 } & \multirow{5}{*}{,426 } \\
\hline & $1-5$ & 3,2017 & 66105 & & \\
\hline & $6-10$ & 3,0997 & 66839 & & \\
\hline & $11-20$ & 3,2135 & 85675 & & \\
\hline & 21 ve üzeri & 3,2705 & ,70497 & & \\
\hline \multirow{5}{*}{ AFAD bilgisi $(\mathrm{AB})$} & 1 yildan az & 2,8000 & 1,09304 & \multirow{5}{*}{3,480} & \multirow{5}{*}{,008 } \\
\hline & $1-5$ & 2,9533 & ,91768 & & \\
\hline & $6-10$ & 2,8376 & ,93958 & & \\
\hline & $11-20$ & 3,4167 & 1,07354 & & \\
\hline & 21 ve üzeri & 3,0514 & ,95001 & & \\
\hline
\end{tabular}

Afetlere hazırlık politikaları alt boyutları ile katılımcıların bulundukları ilde ikamet süresinin karşılaştırılmasına ait ortalama puanları Tablo 13'te görülmektedir. Tabloda görüldüğü gibi bulunulan ilde ikamet süresi değişkenine göre yapılan karşılaştırmada "AFAD bilgisi” alt boyutu ortalama puanları arasında istatistiksel olarak anlamlı farklılık belirlenmiştir $(\mathrm{p}<0,05)$. Katılımcıların AFAD bilgisinin bulunulan ilde ikamet süresi daha yüksek olan katılımcıların ikamet süresi daha az olan katılımcılara göre daha yüksek ortalamaya sahip oldukları görülmüştür $\mathrm{p}<0,05$. 
Diğer taraftan Tabloda görüldüğü gibi afetlere hazırlık politikalarına yönelik algı ölçeğinin bulunulan ilde ikamet süresi değişkenine göre yapılan karşılaştırmada ortalama puanları arasında istatistiksel olarak anlamlı farklılık olmadığı görülmüştür $\mathrm{p}>0,05$. Tablo 14: Katıımcıların afetlere hazırlık politikaları algısı ile alt boyutların Ikametlerinin afet riski olup olmadığı
değişkenine göre karşılaştırılması

\begin{tabular}{|c|c|c|c|c|c|}
\hline Ölçek Alt Boyutları & $\begin{array}{c}\text { İkametin Afet } \\
\text { Riski }\end{array}$ & Ortalama & Std. Sapma & $\mathbf{F}$ & $\mathbf{P}$ \\
\hline \multirow{3}{*}{$\begin{array}{l}\text { İlgili kurumların faaliyetlerine } \\
\text { yönelik alg1 (KFA) }\end{array}$} & Evet & 2,4299 & ,80353 & \multirow{3}{*}{3,819} & \multirow{3}{*}{,023 } \\
\hline & Kismen & 2,6948 & ,77783 & & \\
\hline & Hayır & 2,7016 & ,77210 & & \\
\hline \multirow{3}{*}{$\begin{array}{l}\text { Bütünsel olarak afetlere hazırlık } \\
\text { (BAH) }\end{array}$} & Evet & 1,9747 & 89706 & \multirow{3}{*}{2,616} & \multirow{3}{*}{, 074} \\
\hline & Kismen & 2,2206 & 83358 & & \\
\hline & Hayır & 2,2084 & 84047 & & \\
\hline \multirow{3}{*}{$\begin{array}{l}\text { Afet sonrası bireysel hazırlık } \\
\text { bilinci (ASH) }\end{array}$} & Evet & 3,0582 & ,82394 & \multirow{3}{*}{1,823} & \multirow{3}{*}{, 163} \\
\hline & Kismen & 3,1184 & ,72754 & & \\
\hline & Hayır & 3,2380 & ,75855 & & \\
\hline \multirow{3}{*}{ AFAD'a güven (AG } & Evet & 3,1013 & 68701 & \multirow{3}{*}{,949 } & \multirow{3}{*}{,388 } \\
\hline & Kismen & 3,2164 & ,73641 & & \\
\hline & Hayır & 3,2278 & 67553 & & \\
\hline \multirow{3}{*}{ AFAD bilgisi (AB) } & Evet & 2,9747 & ,97039 & \multirow{3}{*}{,733 } & \multirow{3}{*}{,481 } \\
\hline & Kismen & 2,9502 & 94471 & & \\
\hline & Hayır & 3,0728 & 1,00607 & & \\
\hline
\end{tabular}

Katılımcıların afetlere hazırlık politikaları alt boyutları ile oturdukları evin afet riski taşıma durumu ile karşılaştırılmasına ait ortalama puanları tabloda görülmektedir. Tablo 14'te görüldüğü gibi oturulan evin afet risk durumu değişkenine göre yapılan karşılaştırmada "ilgili kurumların faaliyetlerine yönelik algı" alt boyutu ortalama puanları arasında istatistiksel olarak anlamlı farklılık belirlenmiştir $(\mathrm{p}<0,05)$. İlgili kurumların faaliyetlerine yönelik alg1 alt boyutu itibariyle oturulan evin afet risk durumuna hayır diyenlerin hem evet hem de kısmen diyenlerden anlamlı düzeyde daha yüksek ortalamaya sahip oldukları görülmüştür $(p<0,05)$. Diğer taraftan tabloda görüldüğü gibi oturulan evin afet risk durumu değişkenine göre yapılan karşılaştırmada diğer alt boyutları ortalama puanları arasında istatistiksel olarak anlamlı farklılık belirlenmemiştir ( $\mathrm{p}>0,05)$.

Tablo 15: Katılımcıların afetlere hazırlık politikaları algısı ile alt boyutların hanede yaşayan kişi sayısı değişkenine göre karşılaştırılması

\begin{tabular}{|c|c|c|c|c|c|}
\hline Ölçek Alt Boyutları & İkamette Kişi Sayısı & Ortalama & Std. Sapma & $\mathbf{F}$ & $\mathbf{P}$ \\
\hline \multirow{5}{*}{$\begin{array}{l}\text { İlgili kurumların } \\
\text { faaliyetlerine yönelik } \\
\text { alg1 (KFA) }\end{array}$} & 1 & 2,6231 & ,76339 & \multirow{5}{*}{1,098} & \multirow{5}{*}{,357 } \\
\hline & 2 & 2,7849 & 73063, & & \\
\hline & 3 & 2,6735 & ,73976 & & \\
\hline & 4 & 2,5236 & ,84108 & & \\
\hline & 5 ve üzeri & 2,6586 & 80972 & & \\
\hline \multirow{5}{*}{$\begin{array}{l}\text { Bütünsel olarak } \\
\text { afetlere hazırlık } \\
\text { (BAH) }\end{array}$} & 1 & 2,1140 & 84759 & \multirow{5}{*}{1,493} & \multirow{5}{*}{,203 } \\
\hline & 2 & 2,2069 & 86316 & & \\
\hline & 3 & 2,2498 & 88687 & & \\
\hline & 4 & 1,9920 & ,70361 & & \\
\hline & 5 ve üzeri & 2,2419 & 89954 & & \\
\hline \multirow{5}{*}{$\begin{array}{l}\text { Afet sonrası bireysel } \\
\text { hazırlık bilinci (ASH) }\end{array}$} & 1 & 3,1298 & ,70861 & \multirow{5}{*}{, 193} & \multirow{5}{*}{,942 } \\
\hline & 2 & 3,1478 & ,79308 & & \\
\hline & 3 & 3,2046 & 69011 & & \\
\hline & 4 & 3,1069 & ,78486 & & \\
\hline & 5 ve üzeri & 3,1543 & ,79217 & & \\
\hline \multirow{5}{*}{ AFAD'a güven (AG) } & 1 & 3,2368 & ,73409 & \multirow{5}{*}{2,617} & \multirow{5}{*}{,035 } \\
\hline & 2 & 3,2761 & ,73358 & & \\
\hline & 3 & 3,3362 & ,59504 & & \\
\hline & 4 & 3,0144 & 69504 & & \\
\hline & 5 ve üzeri & 3,1786 & ,73473 & & \\
\hline \multirow{5}{*}{ AFAD bilgisi (AB) } & 1 & 2,9122 & ,95948 & \multirow{5}{*}{,435 } & \multirow{5}{*}{,783 } \\
\hline & 2 & 3,0448 & 89074 & & \\
\hline & 3 & 2,9253 & , 85769 & & \\
\hline & 4 & 2,9885 & 1,03423 & & \\
\hline & 5 ve üzeri & 3,0643 & 1,04373 & & \\
\hline
\end{tabular}


Katılımcıların afetlere hazırlık politikaları alt boyutları ile oturduğunuz evde kaç kişi yaşamaktadır değişkeni karşılaştırılmasına ait ortalama puanları tabloda görülmektedir. Tablo 15'te görüldüğ̈̈ gibi oturulan evde yaşayan kişi sayısı değişkenine göre yapılan karşılaştırmada "AFAD güven” alt boyutu ortalama puanları arasında istatistiksel olarak anlamlı farklılık belirlenmiştir $(\mathrm{p}<0,05)$. Oturulan evde yaşayan kişi sayısı üç kişi olanların katılımcıların AFAD’a güveni diğer gruplara $(1,2,4,5$ ve üzeri) göre daha yüksek ortalamaya sahip oldukları görülmüştür $\mathrm{p}<0,05$. Diğer taraftan tabloda görüldüğü gibi afetlere hazırlık politikalarına yönelik algı ölçeğinin oturulan evde yaşayan kişi sayısı değişkenine göre yapılan karşılaştırmada ortalama puanları arasında istatistiksel olarak anlamlı farklılık belirlenmemiştir p>0,05.

Tablo 16: Katılımcıların afetlere hazırlık politikaları algısı ile alt boyutların afet bilincinin kazandırılması değişkenine göre karşılaştırılması

\begin{tabular}{|c|c|c|c|c|c|}
\hline Ölçek Alt Boyutları & $\begin{array}{c}\text { Afet Bilinci Artırmaya } \\
\text { Yönelik }\end{array}$ & Ortalama & Std. Sapma & $\mathbf{F}$ & $\mathbf{P}$ \\
\hline \multirow{4}{*}{$\begin{array}{c}\text { İlgili kurumların } \\
\text { faaliyetlerine yönelik } \\
\text { alg1 (KFA) }\end{array}$} & Görmedim & 2,4437 & ,82363 & \multirow{4}{*}{11,501} & \multirow{4}{*}{, 000} \\
\hline & Nadiren & 2,7628 & 70948 & & \\
\hline & Ara sıra & 2,9679 & ,64141 & & \\
\hline & Sik sik & 3,1111 & 1,03836 & & \\
\hline \multirow{4}{*}{$\begin{array}{l}\text { Bütünsel olarak } \\
\text { afetlere hazırlık } \\
\text { (BAH) }\end{array}$} & Görmedim & 2,0091 & ,85268 & \multirow{4}{*}{5,666} & \multirow{4}{*}{, 001} \\
\hline & Nadiren & 2,2799 &, 81862 & & \\
\hline & Ara sira & 2,3852 & ,82137 & & \\
\hline & Sik sik & 2,6667 & 1,04527 & & \\
\hline \multirow{4}{*}{$\begin{array}{l}\text { Afet sonrası bireysel } \\
\text { hazırlık bilinci (ASH) }\end{array}$} & Görmedim & 3,0851 & ,70893 & \multirow{4}{*}{2,378} & \multirow{4}{*}{, 069} \\
\hline & Nadiren & 3,1688 & 81391 & & \\
\hline & Ara sira & 3,2537 &, 77612 & & \\
\hline & S1k sik & 3,9000 & 25820 & & \\
\hline \multirow{4}{*}{ AFAD'a güven (AG) } & Görmedim & 3,1325 & ,72352 & \multirow{4}{*}{1,964} & \multirow{4}{*}{, 119} \\
\hline & Nadiren & 3,2388 & 67187 & & \\
\hline & Ara sıra & 3,2809 & ,69864 & & \\
\hline & Sik sik & 3,7500 & ,86603 & & \\
\hline \multirow{4}{*}{ AFAD bilgisi (AB) } & Görmedim & 2,8915 & ,98569 & \multirow{4}{*}{2,207} & \multirow{4}{*}{,087 } \\
\hline & Nadiren & 3,0603 & ,96079 & & \\
\hline & Ara sira & 3,1420 & ,94285 & & \\
\hline & Sik s1k & 3,6234 & ,47929 & & \\
\hline
\end{tabular}

Afetlere hazırlık politikaları alt boyutları ile katılımcıların afet bilincinin kazandırılmasına faaliyetler görme sıklığı değişkeni karşılaştırılmasına ait ortalama puanları tabloda görülmektedir. Tablo 16'da görüldüğ̈ gibi afet bilincinin kazandırılmasına faaliyetler görme sıklığı değişkenine göre yapılan karşılaştırmada "İlgili kurumların faaliyetlerine yönelik algı" ve "Bütünsel olarak afetlere hazırlık" alt boyutları ortalama puanları arasında istatistiksel olarak anlamlı farklılık belirlenmiştir $(\mathrm{p}<0,05)$. Afet bilincinin kazandırılmasına faaliyetler görme sıklığına "sık sık" diyen katılımcıların "ilgili kurumların faaliyetlerine yönelik algı"sının diğer yanıtları veren gruplara (Görmedim, Nadiren ve Ara sıra) göre daha yüksek ortalamaya sahip oldukları görülmüştür $(\mathrm{p}<0,05)$. Benzer şekilde afet bilincinin kazandırılmasına faaliyetler görme sıklığına "sık sık" diyen katılımcıların "bütünsel olarak afetlere hazırlık" düzeyinin diğer yanıtları veren gruplara (Görmedim, Nadiren ve Ara sıra) göre daha yüksek ortalamaya sahip oldukları görülmüştür $(\mathrm{p}<0,05)$. Diğer taraftan tabloda görüldüğü gibi afetlere hazırlık politikalarına yönelik algı ölçeğinin oturulan evde yaşayan kişi sayısı değişkenine göre yapılan karşılaştırmada ortalama puanları arasında istatistiksel olarak anlamlı farklılık belirlenmemiştir (p>0,05).

Tablo 17: Katılımcıların afetlere hazırlık politikaları algısı ile ölçek alt boyutların afet politikalarını yürüten aktörler değişkenine göre karşılaştırılması

\begin{tabular}{|c|c|c|c|c|c|}
\hline $\begin{array}{c}\text { Ölçek Alt } \\
\text { Boyutu }\end{array}$ & $\begin{array}{l}\text { Afet Faaliyetlerini } \\
\text { Yürüten Aktörler }\end{array}$ & Ortalama & $\begin{array}{c}\text { Std. } \\
\text { Sapma }\end{array}$ & $\mathbf{F}$ & $\mathbf{P}$ \\
\hline \multirow{10}{*}{$\begin{array}{c}\text { AFAD } \\
\text { bilgisi (AB) }\end{array}$} & AFAD & 3,0824 & ,84108 & \multirow{10}{*}{2,279} & \multirow{10}{*}{, 017} \\
\hline & AFAD -Valilik & 2,7073 & ,99358 & & \\
\hline & AFAD -Belediye & 2,9565 & ,96428 & & \\
\hline & AFAD -Valilik-Belediye & 3,4348 & 1,12112 & & \\
\hline & AFAD -Valilik-Belediye-Üniversite-Jandarma & 3,3947 & ,75607 & & \\
\hline & Üniversite ve STK'lar & 3,1781 & ,77457 & & \\
\hline & AFAD -Akut & 3,0000 & 1,30931 & & \\
\hline & AFAD -Kızılay & 3,4706 &, 85642 & & \\
\hline & Bilmiyorum & 2,8438 & 1,01514 & & \\
\hline & Boş & 2,9688 & ,96569 & & \\
\hline
\end{tabular}


Tablo 17'de afetlere hazırlık politikaları alt boyutları ile katılımcıların afet politikalarını yürüten aktörlere ilişkin görüşlere verdikleri yanıtların gruplandırılması ile oluşan ortalama puanları karşılaştırılmıştır. Tabloda görüldüğü gibi afet politikalarını yürüten aktörler değişkenine göre yapılan karşılaştırmada "AFAD bilgisi” alt boyutu ortalama puanları arasında istatistiksel olarak anlamlı farklılık belirlenmiştir $(\mathrm{p}<0,05)$. Katılımcılardan afet politikalarını yürüten aktörlere sırasıyla AFAD -Kızılay; AFAD -Valilik-Belediye ve AFAD -Valilik-Belediye-Üniversite-Jandarma yanıtını verenlerin AFAD bilgisinin diğer yanıtları veren katılımcılara daha yüksek ortalamaya sahip oldukları görülmüştür $(p<0,05)$. Diğer taraftan tabloda görüldüğü gibi afetlere hazırlık politikalarına yönelik algı ölçeğinin afet politikalarını yürüten aktörler değişkenine göre yapılan karşılaştırmada ortalama puanları arasında istatistiksel olarak anlamlı farklılık olmadı̆̆ından tabloda yer verilmemiştir ( $\mathrm{p}>0,05)$.

Tablo 18: Katılımcıların afetlere hazırlık politikaları algısı ile ölçek alt boyutların AFAD'ın faaliyet değişkenine göre karşılaştırılması

\begin{tabular}{|c|c|c|c|c|c|}
\hline Ölçek Alt Boyutları & AFAD Faaliyetleri & Ortalama & Std. Sapma & $\mathbf{F}$ & $\mathbf{P}$ \\
\hline \multirow{6}{*}{$\begin{array}{l}\text { İlgili kurumların } \\
\text { faaliyetlerine yönelik alg1 } \\
\text { (KFA) }\end{array}$} & Eğitim-Bilgilendirme & 2,9370 &, 55019 & \multirow{6}{*}{5,803} & \multirow{6}{*}{, 000} \\
\hline & Tatbikat & 3,0280 & 88869 & & \\
\hline & Arama Kurtarma & 3,0082 & ,68627 & & \\
\hline & Deprem Sonrası Çalışmalar & 2,6856 & ,71315 & & \\
\hline & Görmedim & 2,5414 & ,81410 & & \\
\hline & Boş & 2,4790 & ,72224 & & \\
\hline \multirow{6}{*}{$\begin{array}{l}\text { Afet sonrası bireysel } \\
\text { hazırlık bilinci (ASH) }\end{array}$} & Eğitim-Bilgilendirme & 3,3570 & ,88591 & \multirow{6}{*}{4,590} & \multirow{6}{*}{, 000} \\
\hline & Tatbikat & 3,4629 & 69073 & & \\
\hline & Arama Kurtarma & 3,2074 & ,78932 & & \\
\hline & Deprem Sonrası Çalışmalar & 3,4439 & ,70500 & & \\
\hline & Görmedim & 3,0406 & ,73148 & & \\
\hline & Boş & 3,0262 & ,71593 & & \\
\hline \multirow{6}{*}{ AFAD bilgisi $(\mathrm{AB})$} & Eğitim-Bilgilendirme & 3,1395 & ,95322 & \multirow{6}{*}{4,034} & \multirow{6}{*}{, 001} \\
\hline & Tatbikat & 3,3143 & 87520 & & \\
\hline & Arama Kurtarma & 3,3889 & 88070 & & \\
\hline & Deprem Sonrası Calısmalar & 3,3171 & 88569 & & \\
\hline & Görmedim & 2,8461 & .97324 & & \\
\hline & Boş & 2,8929 & ,99417 & & \\
\hline
\end{tabular}

Afetlere hazırlık politikaları alt boyutları ile katılımcıların AFAD'ın hangi faaliyetleri gördükleri değişkeni karşılaştırılmasına ait ortalama puanları arasında sadece anlamlı olanlar Tablo 18'de belirtilmiştir. AFAD’ın hangi faaliyetlerini gördünüz değişkenine "Tatbikat ve Arama-Kurtarma” yanıtını veren katılımcıların "ilgili kurumların faaliyetlerine yönelik algı"sının diğer yanıtları veren gruplara (Eğitim-Bilgilendirme, Deprem Sonrası Çalışmalar, Görmedim ve Boş) göre daha yüksek ortalamaya sahip oldukları görülmüştür ( $p<0,05)$. Benzer şekilde AFAD’ın hangi faaliyetlerini gördünüz değişkenine "Tatbikat, Deprem Sonrası Çalışmalar ve Eğitim-Bilgilendirme” cevabını veren katılımcıların "afet sonrası bireysel hazırlık bilinci" düzeyinin diğer yanıtları veren gruplara (Arama-Kurtarma, Görmedim ve Boş) göre daha yüksek ortalamaya sahip oldukları görülmüştür $(\mathrm{p}<0,05)$. Son olarak AFAD’ın hangi faaliyetlerini gördünüz değişkenine sırasıyla "Arama-Kurtarma, Deprem Sonrası Çalışmalar ve Tatbikat" cevabını veren katılımcıların "afet sonrası bireysel hazırlık bilinci” düzeyinin diğer yanıtları veren gruplara (Eğitim-Bilgilendirme, Görmedim ve Boş) göre daha yüksek ortalamaya sahip oldukları görülmüştür ( $\mathrm{p}<0,05)$.

Tablo 19: Katılımcıların afetlere hazırlık politikaları algısı ile ölçek alt boyutlarının illerinde yapı denetimi değişkenine göre karşılaştırılması

\begin{tabular}{|c|c|c|c|c|c|}
\hline Ölçek Alt Boyutları & $\begin{array}{l}\text { Yapı Denetimi } \\
\text { Yeterliliği }\end{array}$ & Ortalama & Std. Sapma & $\mathbf{F}$ & $\mathbf{P}$ \\
\hline \multirow{3}{*}{$\begin{array}{l}\text { İlgili kurumların faaliyetlerine yönelik alg1 } \\
\text { (KFA) }\end{array}$} & Evet & 2,8519 & 1,19412 & \multirow[t]{3}{*}{14,160} & \multirow[t]{3}{*}{, 000} \\
\hline & Kismen & 2,9192 & 67999 & & \\
\hline & Hayır & 2,5082 & ,78598 & & \\
\hline \multirow{3}{*}{ Bütünsel olarak afetlere hazırlık (BAH) } & Evet & 2,7407 & 1,13685 & \multirow[t]{3}{*}{24,659} & \multirow[t]{3}{*}{,000 } \\
\hline & Kismen & 2,5291 &, 78256 & & \\
\hline & Hayır & 1,9753 & ,80977 & & \\
\hline \multirow{3}{*}{$\begin{array}{l}\text { Afet sonrası bireysel hazırlık bilinci } \\
\text { (ASH) }\end{array}$} & Evet & 3,2000 & ,98489 & \multirow[t]{3}{*}{2,740} & \multirow[t]{3}{*}{,066 } \\
\hline & Kismen & 3,2699 & ,72394 & & \\
\hline & Hayır & 3,0895 & ,76304 & & \\
\hline \multirow[t]{3}{*}{ AFAD'a güven (AG) } & Evet & 3,4167 & ,57282 & \multirow[t]{3}{*}{8,124} & \multirow[t]{3}{*}{,000 } \\
\hline & Kismen & 3,3811 &, 67711 & & \\
\hline & Hayır & 3,1023 & ,70659 & & \\
\hline \multirow{3}{*}{ AFAD bilgisi (AB) } & Evet & 3,1659 & 1,03052 & \multirow[t]{3}{*}{,768 } & \multirow[t]{3}{*}{,465 } \\
\hline & Kismen & 3,0699 & ,91467 & & \\
\hline & Hayır & 2,9988 & ,99736 & & \\
\hline
\end{tabular}


Tablo 19'da afetlere hazırlık politikaları alt boyutları ile katılımcıların bulundukları ilde yapı denetimine verdikleri yanıtlara ait ortalama puanları arasında yapılan karşılaştırılma belirtilmiştir. Bulundukları ilde yapı denetiminin yeterliliğine "kısmen" ve "evet" diyen katılımcıların "ilgili kurumların faaliyetlerine yönelik algısının" "hayır" diyen katılımcılara göre daha yüksek ortalamaya sahip oldukları görülmüştür $(\mathrm{p}<0,05)$. Benzer şekilde "evet" ve "kısmen" yanıtını veren katılımcıların "bütünsel olarak afetlere hazırlık" bilincinin "hayır" yanıtı verenlere göre daha yüksek ortalamaya sahip oldukları görülmüştür $(\mathrm{p}<0,001)$. Son olarak katılımcılardan bulundukları ilde yapı denetiminin yeterliliğine "evet" ve "kısmen" yanıtını veren katılımcıların AFAD güveninin "hayır" yanıtı veren katılımcılara göre daha yüksek ortalamaya sahip oldukları görülmüştür $(\mathrm{p}<0,001)$. Katılımcıların bulundukları ilde yapı denetiminin yeterliliğine verdikleri yanıtlar ile "Afet sonrası bireysel hazırlık bilinci" ve "AFAD bilgisi" değişkenine göre yapılan karşılaştırmada ortalama puanları arasında istatistiksel olarak anlamlı farklılık olmadığı görülmüştür $(p>0,05)$.

\section{Tablo 20: Araştırma hipotezlerinin sonuçları}

\begin{tabular}{|c|c|}
\hline Hipotez & Sonuç \\
\hline $\mathbf{H}_{1 \mathbf{a}}$ : Afetlere hazırlık politikalarına yönelik algı cinsiyete göre anlamlı bir şekilde farklılaşmaktadır. & Kismen Kabul \\
\hline $\mathbf{H}_{1 \mathrm{~b}}$ : Afetlere hazırlık politikalarına yönelik alg1 medeni duruma göre anlamlı bir şekilde farklılaşmaktadır. & Kismen Kabul \\
\hline $\begin{array}{l}\text { H1c: Afetlere hazırlık politikalarına yönelik algı ikametin mülkiyet durumuna göre anlamlı bir şekilde } \\
\text { farklılaşmaktadır. }\end{array}$ & Kismen Kabul \\
\hline $\begin{array}{l}\text { H1d: Afetlere hazırlık politikalarına yönelik algı doğrudan afete maruz kalma durumuna göre anlamlı bir } \\
\text { şekilde farklılaşmaktadır. }\end{array}$ & Kismen Kabul \\
\hline $\begin{array}{l}\text { H1e: Afetlere hazırlık politikalarına yönelik algı katılımeı yakınlarının afete maruz kalma durumuna göre } \\
\text { anlamlı bir şekilde farklılaşmaktadır. }\end{array}$ & Red Edilmiştir \\
\hline $\begin{array}{l}\text { Hıf: Afetlere hazırlık politikalarına yönelik algıları ikamet edilen il açsından anlamlı bir şekilde } \\
\text { farklılaşmaktadır. }\end{array}$ & Red Edilmiştir \\
\hline 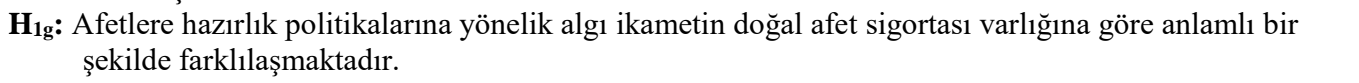 & Kismen Kabul \\
\hline $\mathbf{H}_{1 \mathrm{~h}}$ : Afetlere hazırlık politikalarına yönelik algı ikamet süresine göre anlamlı bir şekilde farklılaşmaktadır. & Kismen Kabul \\
\hline $\begin{array}{l}\mathbf{H}_{11} \text { : Afetlere hazırlık politikalarına yönelik algı ikametin afet risk durumuna göre anlamlı bir şekilde } \\
\text { farklılaşmaktadır. }\end{array}$ & Red Edilmiştir \\
\hline $\begin{array}{l}\mathbf{H}_{\mathbf{1 j}} \text { : Afetlere hazırlık politikalarına yönelik algı ikametteki kişi sayısına göre anlamlı bir şekilde } \\
\text { farklılaşmaktadır. }\end{array}$ & Kismen Kabul \\
\hline $\begin{array}{l}\text { H1k: Afetlere hazırlık politikalarına yönelik algı afet bilincinin kazandırılmasına yönelik faaliyetler görme } \\
\text { değişkenine göre anlamlı bir şekilde farklılaşmaktadır. }\end{array}$ & Kismen Kabul \\
\hline $\begin{array}{l}\text { H11: Afetlere hazırlık politikalarına yönelik algı afet politikalarını yürüten aktörleri bilme değişkenine göre } \\
\text { anlamlı bir şekilde farklılaşmaktadır. }\end{array}$ & Kismen Kabul \\
\hline $\begin{array}{l}\text { H1m: Afetlere hazırlık politikalarına yönelik algı Afad'ın faaliyetlerini görme değişkenine göre anlamlı bir } \\
\text { şekilde farklılaşmaktadır. }\end{array}$ & Kabul Edilmiştir \\
\hline $\begin{array}{l}\text { H1n: Afetlere hazırlık politikalarına yönelik algı yapı denetimi yeterliliği değişkenine göre anlamlı bir } \\
\text { şekilde farklılaşmaktadır. }\end{array}$ & Kabul Edilmiştir \\
\hline
\end{tabular}

\section{Sonuç ve Öneriler}

Afetler meydana geldiği yerde hayatın olağan akışını olumsuz etkilemekle birlikte hem yıkıcı hasarlara hem de sosyokültürel ve ekonomik açıdan pek çok soruna neden olabilmektedir. Özellikle 20. yüzyıldda giderek artış gösteren afet durumlarının neden olduğu sorunların üstesinden gelebilmek için devletler yasal düzenlemeler ve politika yapmak durumunda kalmışlardır. Bu politikaların temel özelliği afetlere karşı toplumun hazırlıklı olmasını sağlamak ve topluma afet bilinci kazandırmaktır. Bir toplumda bireylerin afet veya acil durumlara karşı hazırlıklı olması ve olası bir afet veya acil durumunu sağlıklı bir şekilde yönetebilmesi afet konusunda ilgili paydaşların bu hususta yaptıkları/yapacakları bilinçlendirme faaliyetlerine bağılıdr. Söz konusu bilinçlendirme faaliyetleri ise politika yapıcılar tarafından belirlenir ve ilgili yerde afet risk durumuna göre uygulanır. Bu bakımdan uluslararası düzeyde yapılan anlaşmalar ile doğal afetlerin meydana gelme sıkılığını azaltmaya yönelik tedbirler alınırken, ulusal düzeyde ise devlet tarafından vatandaşın afet bilincini artırmaya yönelik politikalar uygulanmaktadır. Genel olarak devletin ilgili kurumları tarafindan afetlerin neden olduğu olumsuz sonuçlara yönelik afet öncesi, afet esnası ve afet sonrası olmak üzere üç farklı aşamada politika geliştirildiği görülmektedir. Afet öncesi aşamada, özellikle erken uyarı sistemleri sayesinde afetler meydana gelmeden belirli düzeyde önlemler alınmaya yönelik tedbirler yer almaktadır. Afet esnasında ve sonrasında ise vatandaşların olası bir afet veya acil durum türüne göre ne yapmaları gerektiği noktasında belirli bir bilincin kazandırılmasına yönelik faaliyetler yapılmaktadır. Özellikle afet sonrası aşamada ilgili kamu kurumları ve sivil toplum örgütlerinin vatandaşlara yol gösterici olmasının yanı sıra afet zedelere nasıl yardım edileceği hususunda bilgilendirmeler yapılmaktadır. Dolayısıyla afet veya acil durumlara karşı vatandaşların hazırlıklı olabilmeleri etkin bir şekilde uygulanan afet politikalarına bağlıdır. Bu çalışma da Türkiye'nin afetlere hazırlık politikalarının toplum algısı üzerinden karşılaştırmalı analizi yapılmıştır. Araştırma Van Yüzüncü Yıl Üniversitesi ve Bitlis Eren Üniversitesinin akademik ve idari personelinden elde edilen veriler ile gerçekleştirilmiştir. 
Araştırma sonucunda, her iki ilde ortaya çıkan bulgularda; afet hazırlık çalışmaları ve afet bilinci konularında gerçekleştirilen uygulamaların düşük olarak kabul edilebilecek bir düzeyde olduğu, AFAD ve paydaş kurumlar tarafından yapılan çalışmaların yetersiz olduğu görülmüştür. Ayrıca araştırmada, yakın zamanda bir afet yaşanan (Van) ve afet yaşanmayan (Bitlis) illeri arasında bir farklılık olmadığının ortaya çıkması da politika uygulayıcılarının (ilgili kurumların) vatandaşları bilinçlendirme noktasında yeterince etkin olmadıkları şeklinde değerlendirilebilir. Son olarak çalışmanın, eğitim ve öğrenim düzeyinin oldukça yüksek olduğu üniversite personeli üzerinde yapıldığı düşünüldüğünde afetlere hazırlık politikalarının etkililiğinin, görünürlüğünün ve bilinirliliğinin oldukça düşük düzeyde olması da politika yapıcılarının ve uygulayıcılarının faaliyetlerinin oldukça zayıf olduğuna işaret etmektedir.

Araştırmada katılımcıların doğal afet sigortasının varlığına ilişkin sorulara verdikleri yanıtlar Van ve Bitlis illerinde vatandaşların bu hususta yeterli düzeyde bilgiye sahip olmadıkları göstermiştir. Bu bağlamda, ilgili kamu kurumları tarafından toplum doğal afet sigortasının gerekliliğine ve önemine ilişkin detaylı bir şekilde bilgilendirilebilir. Van ve Bitlis illerinin birinci ve ikinci derecede deprem bölgesinde yer aldığı göz önünde bulundurulduğunda bu illerde doğal afet sigortasına ilişkin denetimlerin sıklaştırılması gerektiği söylenebilir. Yine araştırma sonucunda afet bilincinin artmasına yönelik yapılan görsel faaliyetlerin yetersiz olduğu anlaşılmaktadır. Bu bakımdan AFAD ve paydaş kurumların toplumda afet farkındalığının arttırılmasına yönelik görsel vb. materyaller kullanılarak afet bilincinin artması için daha fazla faaliyetleri gerçekleştirmeleri önerilebilir. Ayrıca ilgili kamu kuruluşlarının gerekli denetleme çalışmalarını arttırması önerilmektedir. Katılımcıların kaldığı ildeki ikamet sürelerinin artması ile afet bilgileri doğru orantılı olduğu tespit edilmiştir. AFAD ve belediyeler başta olmak üzere kamu kuruluşları, yerleşim yerlerine yeni gelen bireylere yönelik kentin afetselliği konusunda bilgilendirilme çalışmalarının artırılmasına yönelik faaliyetlere yoğunluk verilmesi önerilmektedir. Son olarak, çalışma bulgularının ülkemizde uygulanan afetlere hazırlık politikalarının etkililiğini tespit edilmesine katkı sunmasının yanı sıra, afet olgusu ile ilgili paydaşlara ve politika yapıcılara yol göstermesi beklenmektedir. Son olarak çalışma Van ve Bitlis illerinde yapıldığından örneklem açısından bir sınırlılık teşkil etmektedir. Bu bakımdan araştırma bulgularının genelleştirilemeyeceğini söyleyebiliriz.

\section{Kaynaklar}

AFAD, (2012), T.C. Başbakanlık Afet ve Acil Durum Yönetimi Başkanlı̆̆ 2013 - 2017 Stratejik Planı, http://www.sp.gov.tr/upload/ xSPStratejikPlan/files/9hMGG+afadsp2013-2017.pdf, [Erişim 26 Aralık 2018].

AFAD, (2018a), AFAD Hakkında, https://www.afad.gov.tr/afad-hakkinda, [Erişim 20 Aralık 2018].

AFAD, (2018b), Bitlis ilinde yaşanan heyelan afeti saylsı, Türkiye Afet Bilgi Bankas1 (TABB) Raporu, https://tabbanaliz.afad.gov.tr/Genel/Raporlar.aspx, [Erişim 16 Aralık 2018].

Akarsu B., Akarsu B., (2019), Bilimsel Araştırma Yöntemleri Bilimsel Araştırma Tasarımı: Nicel, Nitel ve Karma Araştırma Yaklaşımları, Cinius Yayınları, İstanbul, 69ss.

Alkan A., (2015), Bitlis Şehrinin Çevre Sorunları ve Alınması Gereken Önlemler, Doğu Coğrafya Dergisi, 20(33), 11-36.

Arıkan R., (2004), Araştırma teknikleri ve rapor hazırlama, Asil Yayınları, Ankara, 387ss.

Aydın M., (2009), Afet sonrasına yönelik planlama çalı̧̧maları: İzmir örneği, TMMOB İzmir Kent Sempozyumu, 9-11 Ocak, Tepebaşı Kongre ve Sergi Merkezi, İzmir, ss. 115-131.

Azimli Çilingir G., (2018), Türkiye'de uygulanan afet yönetimi politikalarının incelenmesi: yasal düzenlemeler ve Dask, Journal of Resilience, 2(1), 13-21.

Balamir M., (2007), Afet politikası, risk ve planlama, TMMOB Afet Sempozyumu, 5-7 Aralık, İMO Kongre ve Kültür Merkezi, Ankara, ss. 31-43.

Bulut Y., Kara M., (2016), Afet yönetiminde toplumun yeri: Hatay’da bir uygulama, Kamu Yönetiminde Değişimin Yönü ve Etkileri (Kayfor 13 Bildiri Kitab1), 15-17 Ekim 2015, Konya, ss.917-937.

CRED, (2018), Natural disasters in 2017: Lower mortality, higher cost, https://cred.be/sites/default/files/adsr_2017.pdf, [Erişim 4 Aralık 2018].

Cohen L., Manion L., Morrison K., (2005), Research methods in education, 5th Edition, Routledge Falmer, New York, Ny, USA., 446ss.

Çelik M.A., Bayram H., Özüpekçe S., (2017), Türkiye'de son 30 yılda (1987-2017) meydana gelen klimatolojik, meteorolojik ve hidrolojik afetler üzerine bir değerlendirme, Uluslararası Coğrafya ve Coğrafya Eğitimi Dergisi, (38), 295-310.

Doğan B., (2015), Türkiye'de afet yönetim politikalarının analizi: paydaşlar, etkinlik ve sorunlar, 6. Kamu Politikaları Çalıştayı, 1618 Eylül, Sakarya Üniversitesi, Sakarya.

Ekinci R., Büyüksaraç A., Ekinci Y.L., Iş1k E., (2018), Risk assesment of natural disasters for Bitlis province using fine-kinney method, International Conference on Stem and Educational Sciences, 3-5 May, Muş, Turkey.

Elmastaş N., Özcanlı M., (2010), Bitlis ilinde çı̆̆ afet alanlarının tespiti ve çı̆̆ risk analizi, TÜCAUM VI. Coğrafya Sempozyumu, 3 5 Kasım, Ankara Üniversitesi, Ankara, ss.303-313.

Ergünay O., (2009), Afet yönetimi: genel ilkeler, tanımlar, kavramlar, https://www.academia.edu/1983074/Afet_Y\%C3\%B6netimi_ Nedir, [Erişim 05 Ocak 2019].

Ergünay O., Özmen B., (2013), Afet yönetimi açısından Van depreminden elde edilen dersler, 2. Türkiye Deprem Mühendisliği ve Sismoloji Konferans1, 25-27 Eylül, Mustafa Kemal Üniversitesi, Hatay.

Erkal T., Değerliyurt M., (2009), Türkiye'de afet yönetimi, Doğu Coğrafya Dergisi, 14(22), 147-164.

Erkan E.A., (2010), Afet yönetiminde risk azaltma ve Türkiye'de yaşanan sorunlar, DPT Uzmanlık Tezleri, Yayın No:2812, DPT Sosyal Sektörler ve Koordinasyon Genel Müdürlüğü, Ankara., 197ss.

Ersoy Ş., (2009), Afetler Çağı!, https://www.researchgate.net/profile/Suekrue_Ersoy/publication/268740404_Afetler_Cagi/links/549 91eba0cf 2519f5a1defa9/Afetler-Cagi.pdf, [Erişim 18 Ocak 2019]. 
Ertürkmen C., (2006), Afet yönetimi, Yüksek Lisans Tezi, Ankara Üniversitesi Sosyal Bilimler Enstitüsü, Ankara.

Geyik M., (2014), Afet riski altındaki alanlarda kentsel dönüşüm politikaları: Van örneği, Dünya Şehircilik Kolokyumu, 6-8 Kasım, İstanbul Teknik Üniversitesi, İstanbul.

Gökçe O., Özden Ş., Demir A., (2008), Türkiye'de afetlerin mekansal ve istatistiksel dağılımı afet belgeleri envanteri, Bayındırlık ve İskan Bakanlığı, Afet İşleri Genel Müdürlüğü, Afet Etüt ve Hasar Tespit Daire Başkanlığı Ankara, 118ss.

Güler E., (2012), Afet yönetimi cumhuriyet dönemi afet yönetimi mevzuatı ve uygulaması, Doktora Tezi, Gazi Üniversitesi, Ankara.

Gündoğdu O., (2009), Van ve çevresinin deprem tehlikesi, Van Kent Sempozyumu, 1-3 Ekim, Van.

Işı1k E., Özlük M.H., (2012), Bitlis ilinin doğal afetler açısından incelenmesi ve öneriler, Uluslararası Bilim, Teknoloji ve Mühendislik Konferansı, 13-15 Aralık, Dubai.

Iş̧1k Ö., Aydınlığlu H.M., Koç S., Gündoğdu O., Korkmaz G., Ay A., (2012), Afet yönetimi ve afet odaklı sağllk hizmetleri, Okmeydanı T1p Dergisi, 28(2), 82-123.

Işık E., (2013), Bitlis İlinin Depremselliği, Erciyes Üniversitesi Fen Bilimleri Enstitüsü Dergisi, 29(3), 267-273.

İMO, (2010), Türkiye Deprem Bölgeleri Haritast, http://www.imo.org.tr/resimler/dosya_ekler/ff019c60caaf76b_ek.pdf?tipi=84\& turu $=X \&$ sube $=0$, [Erişim 11 Ocak 2019].

Kadığlu M., Özdamar E., (2008), Afet Zararlarını Azaltmanın Temel İlkeleri, JICA Türkiye Ofisi, Yayın No:2, Ankara.

Kadıŏlu M., (2011), Afet yönetimi beklenilmeyeni beklemek, en kötüsünü yönetmek, T.C. Marmara Belediyeler Birliği Yayınları, Yayın No:65, İstanbul.

Kadıŏlu M., (2012), Türkiye’de İklim Değişikliği Risk Yönetimi, Türkiye’nin İklim Değişikliği II. Ulusal Bildiriminin Hazırlanması Projesi Yayın1, Ankara, 172ss.

Kalelioğlu E., (2018), Van ovasinın iklim özellikleri, Dil Tarih Coğrafya Dergisi, 35(2), 155-166.

Karancı A.N., Kalaycıŏglu S., Başbuğ Erkan B.B., Özden A.T., Çalışkan İ., Özakşehir G., (2011), Tabanl1-Van (23 Ekim 2011$)$ ve Edremit-Van (9 Kasım 2011) Depremleri İnceleme Raporu, Ortadoğu Teknik Üniversitesi Afet Yönetimi Uygulama ve Araştırma Merkezi, Ankara, 74ss.

Karasar N., (1999), Bilimsel Araştırma Yöntemi, Nobel Yayın Dağıtım, Ankara.

Laçiner V., Yavuz Ö., (2013), Van Depremi Örneğinde Afetler Sonrası Yapılan Yardımlar ve Hukuki Çerçevesi, Dicle Üniversitesi Sosyal Bilimler Enstitüsü Dergisi, 5(9), 114-135.

Macit İ., (2019), Bütünleşik Afet Yönetiminde Sendai Çerçeve Eylem Planının Beklenen Etkisi, Doğal Afet ve Çevre Dergisi, 5(1), 175186.

MTA, (2010), Bitlis ili maden ve enerji kaynaklarl, T.C. Maden Tetkik ve Araştırma Genel Müdürlüğü, http://www.mta.gov.tr/v3.0/sayfalar/bilgi-merkezi/maden_potansiyel_2010/Bitlis_Madenler.pdf, [Erişim 10 Ocak 2019].

OGM, (2013). Yukarl havza sel kontrolü eylem planı 2013-2017, T.C. Orman ve Su İşleri Bakanlığı, https://www.ogm.gov.tr/ ekutuphane/Yayinlar/Yukar\%C4\%B1\%20Havza\%20Sel\%20Kontrol\%C3\%BC\%20Eylem\%20Plan\%C4\%B1.pdf, [Erișim 10 Aralık 2018].

Özcan E., (2006), Sel Olayı ve Türkiye, Gazi Eğitim Fakültesi Dergisi, 26(1), 35-50.

Özkaya Y., Erat V., (2017), Türkiye'de afetlerin hukuki, kurumsal ve bilimsel izdüşümleri, Belediyelerin Geleceği ve Yeni Yaklaşımlar II.Cilt'in İçinde (Güler M., Turan A.M., Ed.), Marmara Belediyeler Birliği Kültür Yayınları, Şan Ofset, İstanbul, ss. 351-367.

Özkul B., Karaman A.E., (2007), Doğal afetler için risk yönetimi, TMMOB Afet Sempozyumu, 5-7 Aralık, İMO Kongre ve Kültür Merkezi, Ankara, ss.251-260.

Özmen B., Özden T., (2013), Türkiye'nin afet yönetim sistemine ilişkin eleştirel bir değerlendirme, İ.Ü. Siyasal Bilgiler Fakültesi Dergisi, 49, 1-28.

Özşahin E., (2013), Türkiye'de yaşanmış (1970-2012) doğal afetler üzerine bir değerlendirme, 2. Türkiye Deprem Mühendisliği ve Sismoloji Konferans1, 25-27 Eylül, Mustafa Kemal Üniversitesi, Hatay.

Şahin G., (2016), Yerel yönetimlerde afetlere hazırlık ve zarar azaltma sorumlulukları, Kamu Yönetimi Sempozyumu, 5-7 Mayıs, İzmir.

Taştan B., Aydınoğlu A.Ç., (2015), Çoklu afet risk yönetiminde tehlike ve zarar görebilirlik belirlenmesi için gereksinim analizi, Marmara Coğrafya Dergisi, (31), 366-397.

Tercan B., (2018), Türkiye'de afet politikaları ve kentsel dönüşüm, Abant Kültürel Araştırmalar Dergisi, 3(5), 102-120.

TMMOB, (2012), Türkiye'de Deprem Gerçeği ve TMMOB Makine Mühendisleri Odası'nın Önerileri, TMMOB Makine Mühendisleri Odas1, http://www1.mmo.org.tr/resimler/dosya_ekler/d4419b4a44bde5f_ek.pdf, [Erişim 10 Şubat 2019].

Ulaş Kadığlu B., Uncu F., (2018), Disaster Awareness Research in Family Health Centers: The Case of Elazig, Journal of Current Researches on Health Sector, 8(2), 1-10.

URL-1, (2018), General classification, https://www.emdat.be/classification, [Erişim 6 Aralık 2018].

URL-2, (2014), Onuncu Kalkınma Planı (2014-2018) Özel İtisas Komisyonları El Kitabı, T.C. Kalkınma Bakanlığı, http://www.sbb.gov.tr/wpontent/uploads/2018/10/Onuncu_Kalk\%C4\%B1nma_Plan\%C4\%B1_\%C3\%96zel_\%C4\%B0htisas_Ko misyonlar\%C4\%B1_El_Kitab\%C4\%B1.pdf [Erişim 11 Aralık 2018].

URL-3, (2002), 8. Kalkınma Planı, T.C. Kalkınma Bakanlığı, http://www3.kalkinma.gov.tr/DocObjects/View/769/destek02.pdf, [Erişim 20 Aralık 2018].

URL-4, (2013), 10. Kalkınma Planı, T.C. Kalkınma Bakanlığı, http://www.sbb.gov.tr/wp-content/uploads/2018/11/OnuncuKalk\%C4\%B1nma-Plan\%C4\%B1-2014-2018.pdf, [Erişim 20 Aralık 2018].

UNISDR, (2009). Terminology on disaster risk reduction, https://www.unisdr.org/files/7817_UNISDRTerminologyEnglish.pdf, [Erişim 15 Ocak 2019]. ${ }^{\mathrm{i}}$ 